\title{
47. A REAPPRAISAL OF ANOXIA AND RICHNESS OF ORGANIC MATERIAL, WITH EMPHASIS ON THE CRETACEOUS NORTH ATLANTIC ${ }^{1}$
}

\author{
Douglas W. Waples, Mobil Research and Development Corporation, Dallas ${ }^{2}$
}

\begin{abstract}
Accumulation of anoxic sediments in the North Atlantic from Barremian through Turonian time (Early to middle Cretaceous) was apparently controlled mainly by local conditions, although global climatic and oceanographic factors may have played a supporting role. Evidence does not support the popular hypothesis developed over the past few years of global or ocean-wide anoxia. The data contradicting this hypothesis are based on a reevaluation of criteria for identifying sediments that accumulated in anoxic water, a critical reappraisal of reported world-wide occurrences of anoxic sediments of these ages, and an examination of the spatial and temporal distribution of anoxic sediments in the North Atlantic and elsewhere. A model is proposed in which the earliest anoxic sediments of Cretaceous age in the North Atlantic were deposited in deep restricted basins. By middle Cenomanian time (about 97 m.y. ago), however, sluggish circulation had led to a gradual expansion of the oxygen-minimum layer, permitting deposition of anoxic sediments in nonbasinal settings. The expansion of the oxygen-minimum layer caused the calcite compensation depth to rise, promoting oxidation of organic carbon and causing contraction of the oxygen-minimum layer. The development of anoxia was thus self-damping. Anoxia effectively disappeared by early Senonian time ( $88 \mathrm{~m} . \mathrm{y}$. ago) when improved circulation created oceans more like those of the present. Some evidence indicates that enhanced productivity and upwelling may have played a local role in fostering anoxia, but most data suggest that worldwide marine productivity was generally not high during Early and middle Cretaceous time.
\end{abstract}

\section{INTRODUCTION}

In the past few years extensive interest has developed in dark-colored sediments of Barremian to Turonian age, slightly to highly enriched in organic matter, that commonly occur in the North Atlantic Ocean. Schlanger and Jenkyns (1976) proposed that these sediments were deposited during "oceanic anoxic events" when large portions of the water column became severely or totally depleted in oxygen. They suggested that such events were at least of oceanic scale and may have been global. Subsequently, Arthur (1979) has become an advocate of ocean-wide anoxia in bottom waters as being a decisive factor in the preservation of organic matter. The possible importance of anoxic waters in the deposition of future source sediments for oil (e.g., Demaison and Moore, 1980) has recently caused the petroleum industry to show considerable interest in Cretaceous anoxia.

The above authors, along with Arthur and Schlanger (1979), Jenkyns (1980), and Hart and Bigg (1981), have perceptively pointed out occurrences of dark-colored sediments rich in organic matter of similar ages from various areas. Nevertheless, the hypothesis of widespread anoxia in Cretaceous waters has not been carefully examined until now, although it has for some time been widely accepted without challenge. A more detailed analysis of the evidence in fact reveals that many supposed anoxic sediments were more likely deposited under oxic conditions and are therefore not indicative of Cretaceous anoxic events.

\footnotetext{
${ }^{1}$ Graciansky, P. C. de, Poag, C. W., et al., Init. Repts. DSDP, 80: Washington (U.S. Govt, Printing Office)

2 Present address: 1717 Place One Lane, Garland, TX 75042.
}

I shall show that many sediments of Barremian to Turonian age previously thought to have been deposited under anoxic conditions were more likely laid down in moderately to well-oxygenated waters; that evidence for global distribution of sediments deposited under anoxic conditions during the Barremian-Turonian interval is meager; and that the use of the term oceanic is inappropriate for the North Atlantic during Barremian to Turonian time. Furthermore, although there is evidence that many sites in the North Atlantic simultaneously suffered from oxygen deficiency during the mid-Cretaceous, the deficiency most likely consisted of brief episodes of near or total anoxia that alternated with more extended periods of good oxygenation. This pattern is consistent with local control of oxygen levels rather than ocean-wide anoxia. Finally, I will attempt to show that mechanisms currently offered to account for the anoxic episodes in the Early and middle Cretaceous ${ }^{3}$ North Atlantic are unsatisfactory and will propose an alternative explanation for deposition of laminated, organic-carbon-rich sediments.

\section{RICHNESS OF ORGANIC MATTER}

One of the main problems in discussing the origin of rocks and sediments enriched in organic matter is the variable use of the term black shale, which commonly implies enrichment in organic matter (e.g., Devonian black shale of the eastern United States; Kimmeridgian black shale of the North Sea). Many black shales, however, are not highly enriched in organic matter. Arthur

\footnotetext{
${ }^{3}$ An informal term used interchangeably in this paper with "Barremian to Turonian."
} 
(1979), for example, used "black shale" (his quotation marks) as a general term for

relatively organic-rich (i.e., $>0.5$ wt. $\% \mathrm{C}_{\text {org }}$ ), dark-colored (dark gray, greenish black, and black) mudstone and marlstone which may or may not be "shale" in the classical sense.

This definition is not very selective, because as Arthur and Natland (1979) have noted, it encompasses all dark-colored rocks having organic carbon values above the average for pelagic rocks. Other authors have used terms such as carbonaceous shale (Schlanger and Jenkyns, 1976), bituminous sediments (Brumsack, 1980), bituminous facies (Jenkyns, 1980), black clays (Kendrick, 1979), and black mudstones (McCave, 1979), either without clearly defining their selection criteria or by defining them with an arbitrary organic carbon content (e.g., $1 \%$ : Brumsack, 1980). I have chosen to avoid the use of all of these terms, including black shale, and have instead divided dark-colored rocks and sediments into two categories as suggested by Ryan and Cita (1977): those deposited in moderately to well-oxygenated waters and those deposited in bottom waters in which oxygen was either totally lacking or severely depleted.

The sediments cited by Schlanger and Jenkyns (1976), Arthur (1979), Jenkyns (1980), and numerous DSDP investigators (see Arthur [1979] for a more complete listing) as black shales, bituminous shales, etc. were probably deposited mainly in oxygenated waters. This conclusion is based on their moderate organic carbon contents (rarely exceeding 2\%), their color (gray to dark gray), and their sedimentary structures (bioturbated or homogeneous). If indeed these are oxic sediments, they cannot be used as evidence of anoxia in the Cretaceous North Atlantic.

The terms anoxic sediments and laminated, organicrich sediments will be used interchangeably to refer to sediments deposited either under very low oxygen conditions or under truly anoxic conditions. The term anoxic is not strictly correct unless oxygen is totally absent, but this distinction has often been ignored by other workers and is not important in the present context. In contrast to oxic sediments, sediments deposited under anoxic or nearly anoxic conditions are rich in organic matter $(>2$ $\mathrm{C}_{\text {org }}$, with examples $>10 \%$ being plentiful), dark-colored, sometimes pyritic, phosphatic, or both, and laminated on a millimeter or submillimeter scale (Demaison and Moore, 1980). Absence of burrowing infauna and lack of current and wave activity are responsible for preservation of depositional laminae. The organic matter may be of marine or terrestrial origin or a mixture of both. Pyrite is not a good indicator of anoxic bottom waters, because it commonly forms in anoxic microenvironments that exist within otherwise oxidizing sediments and in sediments that became anoxic only after burial. Conversely, the absence of pyrite does not indicate oxic conditions, because pyrite formation can be prevented even under anoxic bottom-water conditions by a lack of iron, usually as a result of the absence of clay minerals.

The organic carbon content of a sediment can be a useful indicator of depositional environment, because it is intricately related to the oxygen content of the overlying water mass. The level of dissolved oxygen in bottom waters represents a dynamic equilibrium between depletion, mainly by decay of organic matter, and replenishment by oxygen-bearing bottom currents. An organicrich mud will place a much greater demand on the oxygen supply of the bottom water than will an organic-poor mud. As long as the dissolved-oxygen level in the bottom water exceeds about $0.2 \mathrm{ml} / 1$, benthic activity, including scavenging and burrowing, can occur (Rhoads and Morse, 1971; Douglas, 1981). Sediments deposited under such conditions usually bear evidence of bioturbation. At lower oxygen levels, however, most forms of benthic organisms cannot survive, and sedimentary laminations are preserved. Burrowers and scavengers depart first, followed by Foraminifera; eventually only anaerobic bacteria remain active.

Anaerobic bacteria are relatively ineffective in metabolizing organic matter (many are highly selective in the organic compounds they can decompose) and are limited ultimately by the supply of electron acceptors for metabolic processes (Demaison, 1981). Sulfate ions are the most common electron-accepting substrates; their concentration in sediments is limited by the initial sulfate-ion concentration of pore water and by the rate of diffusion of sulfate into the sediment from the overlying water column.

When sediments contain enough reactive organic matter to completely exhaust the oxygen in the bottom waters, those waters will remain anoxic until either the rate of oxygen consumption decreases or the rate of oxygen influx increases. The amount of molecular oxygen available can be raised by an increase in the circulation of oxygen-bearing water, an increase in the oxygen content of the water already circulating, a decrease in influx of organic matter, a change in the type of organic matter, or a decrease in the rate of burial. Any or all of these factors may be important in a given instance. Whenever bottom waters are anoxic, significant amounts of organic carbon will be preserved.

How much organic matter is required within a sediment for total oxygen depletion to occur depends on a myriad of factors that affect oxygen availability and consumption. Consumption rates are a function of the supply of both organic and inorganic material and the type of organic material present (Heath et al., 1977). Benthic macro- and microorganisms readily oxidize algal (phytoplankton) remains because the chemical composition and balance of essential nutrients in algae, especially nitrogen and phosphorus, are nutritionally ideal. In contrast, terrestrial organic debris, particularly woody material, is depleted in nitrogen and phosphorus. Because much organic carbon from terrestrial sources is refractory, one unit of woody organic matter places a much smaller oxygen demand on the sediment-water system than does one unit of phytoplankton remains (Tissot et al., 1979).

Furthermore, terrestrial organic materials usually have much lower surface area/volume ratios than do phytoplankton remains and will therefore degrade more slowly. Slowing the rate of degradation by decreasing surface area/volume ratios is equivalent to slowing degradation by increasing the sediment accumulation rate (Heath et 
al., 1977; Müller and Suess, 1979; Ibach, 1982) and will lead to preferential preservation of terrestrial organic matter compared to phytoplankton remains. Finally, the bactericidal decomposition products of tannin and lignin from woody material retard decomposition.

The quantity of organic matter required to induce anoxia in bottom waters in one setting may thus be completely inadequate in another. Numerous DSDP investigations (e.g., Davies et al., 1974; Heirtzler et al., 1974) have shown that pelagic sediments containing at least $2 \%$ organic carbon of predominantly terrestrial origin are sometimes extensively burrowed and show other evidence of having been deposited under oxygenated water. Extensive burrowing occurred in littoral sediments of Barremian age from the North Atlantic that contained up to $6 \%$ organic carbon in the form of macroscopic wood and leaf debris (de Graciansky et al., this volume). Organic material of marine origin, however, need not be present in such large quantities to induce anoxia in bottom waters (Tissot et al., 1979). For example, an English black chalk, deposited in an anoxic environment in a mid-Cretaceous epeiric sea, was found to contain only $1.1 \%$ organic carbon (Schlanger and Jenkyns, 1976).

Unless the organic matter in sediments is of phytoplanktonic origin or unless independent evidence suggests that the water column itself was anoxic, we therefore should not assume that above-average carbon contents necessarily indicate anoxia in bottom waters (Ryan and Cita, 1977; Habib, 1982). For example, although relatively high concentrations of organic carbon (up to $3 \%$ ) occur in Lower Cretaceous sediments at DSDP Sites 105 and 398 , this organic matter, which was already highly oxidized at the time of its entry into the water column, could not have significantly affected the oxygen content of the bottom waters (Tissot et al., 1979; de Graciansky et al., 1982).

Thus it becomes apparent that the highly organic-carbon-rich, laminated, black or blackish sediments should be the focus of investigations into possible anoxic events in the North Atlantic. The distinction between terrestrial and marine organic matter is important because of their different capacities to induce anoxia. High organic-carbon contents are necessary but not sufficient criteria for bottom-water anoxia. Preserved depositional laminations, on the other hand, are excellent indicators of low oxygen contents.

\section{EVIDENCE AGAINST GLOBAL ANOXIC EVENTS}

According to some current hypotheses, ocean waters were globally depleted in oxygen at two or three times during Barremian to Santonian time (Schlanger and Jenkyns, 1976; Arthur and Schlanger, 1979; Jenkyns, 1980). It is thought that these events led to formation of expanded oxygen-minimum layers and fostered development of anoxia in waters with even mildly restricted circulation or slightly elevated biological productivity. These "oceanic anoxic events" (those authors believe) resulted in prolific deposition of dark-colored, organic-rich muds that later became what they have called "black shales" and "bituminous facies." In support of this hypothesis they offered as evidence numerous examples of darkcolored rocks that are relatively rich in organic content, of Barremian to Santonian age, and from a variety of settings around the world.

I submit, however, that most of these examples are not laminated, organic-rich sediments deposited under anoxic conditions but that they are instead only moderately rich in organic matter and deposited under significantly more oxidizing conditions. Other examples seem to be indicative of local anoxic events unrelated to any global oxygen depletion.

\section{Pacific Ocean}

Laminated, dark-colored radiolarian cherts and shales from plateaus in the Pacific Ocean, for example, were cited by Jenkyns (1980) and Schlanger and Jenkyns (1976) as evidence for global anoxia. ${ }^{4}$ Descriptions of these sediments in the original DSDP reports (Larson et al., $1975 \mathrm{a}, \mathrm{b}, \mathrm{c})$ indicate that they were apparently deposited in anoxic waters. These anoxic waters, however, probably developed as a result of high surface productivity associated with the plate-tectonic movement of these oceanic plateaus across the highly fertile equatorial belt during Cretaceous time (Schlanger and Jenkyns, 1976; Lancelot and Larson, 1975; Jenkyns, 1980; Dean, Claypool, et al., 1981), and therefore represent local anoxic events rather than global ones. This view is also supported by W. Dean's observation (personal communication, 1982) that organic-rich sediments found in the $\mathrm{Pa}$ cific Ocean are not coeval but were rather deposited sporadically over an interval spanning more than 30 m.y. from late Neocomian to Turonian time.

The deposition of sediments rich in organic matter on topographic highs seems odd by comparison with most ancient and modern settings, because it is easier to create anoxia in bottom waters in topographic lows where sills can restrict circulation. Circulation of oxygenated waters can also be prevented on a topographic high, however, if the high protrudes into a well-defined oxygen-minimum layer (Thiede and van Andel, 1977; Ryan and Cita, 1977; Pisciotto and Garrison, 1981). A seamount or plateau protruding a few thousand meters above the surrounding abyssal plain could project into an intense oxygen-minimum layer like that present beneath the equatorial zone of high photosynthetic productivity in the modern Pacific Ocean.

One organic-carbon-rich sediment that is described by Schlanger and Jenkyns (1976) is a highly carbonaceous $\left(28.7 \% \mathrm{C}_{\text {org }}\right)$ volcaniclastic sandstone from the Manihiki Plateau in the Pacific Ocean. The carbonaceous layer is over- and underlain by sediments containing less than $0.1 \%$ organic carbon. The sandstone contains bivalves (Jenkyns, 1976), a fauna not expected in anoxic waters. Except for its extremely high organic-carbon content, this layer has little in common with laminated, organic-rich, fine-grained sediments of anoxic environments. The sandstone probably represents a catastrophic ash fall that killed the benthos and preserved

\footnotetext{
4 According to Jenkyns (1980) and Garrison (1981), the Black Calera Limestone of the Franciscan Formation of California should also be included here.
} 
the underlying organic carbon. Although the ash fall apparently sealed off the old seafloor and thereby induced subsurface anoxia, it did not create anoxia in the bottom waters because sediments immediately above the carbonaceous layer are almost devoid of organic carbon.

\section{Indian Ocean}

Schlanger and Jenkyns (1976) also cited data from DSDP Sites 258 and 263 in the Indian Ocean as indicative of a global anoxic event. Those sediments are bioturbated, however, and only contain about $1 \%$ organic carbon (Davies et al., 1974; Heirtzler et al., 1974). Heirtzler et al. (1974) proposed a continental provenance for much of the organic material at Site 263, an interpretation which suggests that the organic matter was refractory and unlikely to induce anoxia.

\section{Tethys Ocean}

Numerous examples of dark-colored Alpine shales, many of them laminated and very rich in organic matter, were discussed by Jenkyns (1980), who suggested that they were deposited in deep basins along the margin of the Tethys Ocean. These basins were separated from each other by submarine plateaus (Weissert et al., 1979). Slumping and redeposition were apparently common within these basins and were important in controlling sediment accumulation rates (Weissert et al., 1979). Many of the organic-rich strata are associated with flysch deposits (Bernoulli and Jenkyns, 1974; Jenkyns, 1980). In cases where turbidity currents were responsible for deposition of organic-carbon-rich strata, bottom waters at the depositional site need not have been anoxic (Meyers et al., 1981; Dean, Barron, et al., 1981).

Furthermore, even if some or all of the Alpine sediments were deposited in anoxic water, there is no compelling evidence to suggest that anoxia was of a regional scale. Local anoxia may have been particularly important in some small and relatively shallow local depressions on the Trento Plateau (Jenkyns, 1980) and in the Lombardian Basin (Weissert et al., 1979), where numerous organic-carbon-rich strata were deposited. The presence of phosphatic hardgrounds on the Trento Plateau (Jenkyns, 1980) is indicative of reducing conditions during the original precipitation of biogenic phosphate, followed by oxidizing conditions during formation of the hardground (Waples, 1982). The change in bottom-water conditions from oxygen-poor to oxygen-rich could just as easily be explained by local changes in circulation, sea level fluctuations, or injection of salty anoxic plumes from nearby shelves (Hay, 1982) as by larger scale changes in the oxygen content of the oceans.

Tectonic movements related to subduction and transform faulting along active margins are important in creating many local basins in which laminated, organicrich sediments can be deposited (e.g., Southern California during Tertiary time [Ingle, 1980]) and were undoubtedly important in the western Tethys Ocean during mid-Cretaceous time (North, 1980). A disproportionately large amount of the world's sediment accumulates in active-margin basins under conditions that foster preservation of organic material (e.g., rapid burial and re- stricted circulation), and these basins are atypical of pelagic environments in general (Howell and von Huene, 1981).

The Southern California Borderland may be a useful model for Tethyan depositional settings. Anoxia prevails locally today in some of the numerous silled basins of the Borderland, whereas other basins are oxygenated (Emery, 1960). Oxygen levels in these basins have probably fluctuated widely and rapidly in response to tectonically induced variations in sill depth and to eustatic sea level changes.

\section{Marginal Settings and Epeiric Seas}

Attempting to discern patterns of oxygenation of oceanic waters by observing sediments deposited in marginal settings is of limited value because oxygen levels in waters of marginal basins may not be typical of pelagic settings in general. Rates of primary photosynthetic productivity along continental shelves or over the upper continental slope are much higher than in more seaward locations, except along the Pacific equatorial belt of high productivity (King and Hida, 1957). Except where they lie within the zone of wave turbulence, waters underlying these productive zones will exhibit more intense oxygen-minimum layers than will waters farther from shore (Wyrtki, 1962).

Examples cited by Jenkyns (1980) from numerous Cretaceous sediments in continental margin basins (Peru, Venezuela, Caribbean, and the Middle East) thus cannot be used as indicators of oxygen levels in the open ocean at those times. Furthermore, some of the rocks Jenkyns cites were not definitely shown to be rich in organic matter: for example, black chert is commonly poor in organic matter, the black color apparently arising from the silica matrix itself (Waples, unpublished data).

The carbonaceous epeiric facies discussed by Jenkyns (1980) are likewise poor indicators of anoxia because oxygen levels in ancient epeiric seas were dependent upon numerous factors in addition to the oxygen level of the open ocean. Wave and tidal friction were important in reducing circulation within epeiric seas (Shaw, 1964), and the oxygen content of an epeiric sea was predominantly influenced by local topography, size of the sea, rates of evaporation, inflow of fresh water, and the level of primary photosynthetic productivity. The occurrence of laminated, organic-rich sediments in epeiric seas is therefore, in general, poor evidence for oceanic anoxia.

\section{South Atlantic Ocean}

Evidence for widespread anoxia during Early and middle Cretaceous time is most abundant in the South Atlantic Ocean. Data summarized by Thiede and van Andel (1977) and Arthur and Natland (1979) and supplemented by Meyers et al. (1981) and Dean, Barron, et al. (1981) show that numerous examples of laminated, organic-rich sediments occur at a variety of sites in the South Atlantic. It is unknown, however, whether the organic-rich sediments were deposited within oxygen-minimum layers (Thiede and van Andel, 1977) or within anoxic basins that developed as a result of salinity stratification (Arthur and Natland, 1979). 
Anoxia in the South Atlantic, however, is probably not indicative of a world-wide trend toward oceanic oxygen impoverishment because communication between the South Atlantic and other oceans was very poor during Early and middle Cretaceous time. The deep-water connection with the North Atlantic was probably either nonexistent or intermittent until Turonian time (Sclater et al., 1977), and the Falkland Plateau probably acted as a sill that isolated the proto-South Atlantic from circulation to the south (LePichon, Eittreim, et al., 1971; LePichon, Ewing, et al., 1971; Arthur and Natland, 1979). The extensive salt deposits at the northern end of the proto-South Atlantic embayment (Leyden et al., 1972; Evans, 1978;) support a model with restricted circulation. Conditions within the proto-South Atlantic basins during Early and middle Cretaceous time were therefore probably not representative of those in the open ocean.

The model proposed by Arthur and Natland (1979) for the South Atlantic, and more tentatively for the North Atlantic, and extended by Hay (1982) to the Western Interior Seaway (in the United States) invokes salinity-induced stratification as the effective mechanism of oxygen depletion in basinal bottom waters. Such stratification is known locally in modern oceans (e.g., Addy and Behrens, 1980). The model of Thiede and van Andel (1977), based on the existence of a well-developed oxygen-minimum layer in the proto-South Atlantic, is also the extension of a modern oceanic phenomenon to an ancient setting. Both the oxygen-minimum and anoxicbasin models would still be applicable if ancient oceanic waters were less oxygenated than those of the modern oceans, but neither model depends critically upon lower oxygen levels. One or the other of these models, along with locally important influx, burial, and preservation of organic matter by turbidity currents (Meyers et al., 1981; Dean et al., 1981a), offers the simplest explanation for formation of laminated, organic-rich sediments in the Cretaceous South Atlantic, without necessarily invoking oceanic or world-wide anoxia.

\section{Discussion}

Evidence for global anoxia in Early and middle Cretaceous oceans is therefore simply not compelling: occurrences of black shales probably represent either sediments deposited under oxic conditions or anoxic conditions of only local significance. Local emplacement of anoxic sediments resulting from high productivity, welldeveloped oxygen-minimum layers, restricted circulation, or turbidity currents does not require global depletion of dissolved oxygen. Granted, Cretaceous oceans were probably not as highly oxygenated as the modern oceans, according to paleoclimatological analysis (e.g., Fischer and Arthur, 1977). Nevertheless, a slight general depletion of oxygen apparently did not lead to global or oceanic anoxia nor to deposition of anoxic sediments in environments that are oxidizing in modern oceans.

An alternative hypothesis is that rifting and plate movements, along with widespread transgressions (e.g., Vail et al., 1977), played a critical role in creating an unusually large number of marginal basins (North, 1980), which by Early to middle Cretaceous time were suffi- ciently deep to induce patterns of sluggish bottom-water circulation. Anoxia eventually developed in these bottom waters, perhaps promoted by instances of high productivity, but such anoxia was relatively local and sporadic. The pattern of anoxia in marginal basins has been well documented by Jenkyns (1980) and need only be reinterpreted as a series of local occurrences linked together in a tectonic framework, rather than as global anoxia.

\section{EVIDENCE AGAINST OCEANIC ANOXIC EVENTS}

\section{Definition of Ocean}

One important argument against the occurrence of anoxic events of oceanic dimension during Early to middle Cretaceous time is that neither the North nor the South Atlantic-the two areas for which we have the strongest evidence for multiple occurrences of laminated, organic-rich sediments-was at that time an ocean in the modern sense. This distinction is important because our understanding of the term oceanic is based on modern analogs. The South Atlantic in particular was a small, highly restricted sea, similar to the modern Gulf of California in size, geometry, bathymetry, and degree of connection to other bodies of water (Thiede and van Andel, 1977). I therefore prefer to drop the term oceanic in my discussion of possible anoxia in the proto-North and South Atlantic regions.

\section{Temporal and Spatial Relationships of Anoxic Sediments in the North Atlantic}

A second argument against the occurrence of several widespread anoxic events in the North Atlantic is the pattern of accumulation of laminated, organic-rich sediments. Charts that show the temporal relationships of black shales during Cretaceous time have been published by Arthur (1979) and Tucholke and Vogt (1979), but as I have shown, many of the sediments cited probably did not accumulate under anoxic conditions. I have therefore reevaluated the geologic evidence from the individual Deep Sea Drilling Project site chapters and, where available, from the organic geochemical studies reported in the appropriate volumes of Initial Reports of the Deep Sea Drilling Project. Figure 1 shows occurrences of both laminated, organic-rich and nonlaminated, nonorganic-rich sediments of Early to middle Cretaceous age in the North Atlantic. Descriptions of the laminated, organic-rich sediments are given in Table 1. Figures 2-6 show known locations of laminated, organicrich and non-organic-rich sediments at five different times during the Early and middle Cretaceous. These particular times were chosen to correspond to the maps prepared by Sclater et al. (1977).

The overall picture that emerges from Figures 1 through 6 is that anoxic sediments were deposited mainly during Albian through Turonian time. The distribution of these sediments apparently has a single maximum at the Cenomanian-Turonian boundary. Black, laminated, organic-rich sediments were probably absent in the North Atlantic until late Hauterivian or early Barremian time and disappeared at the end of the Turonian, although 


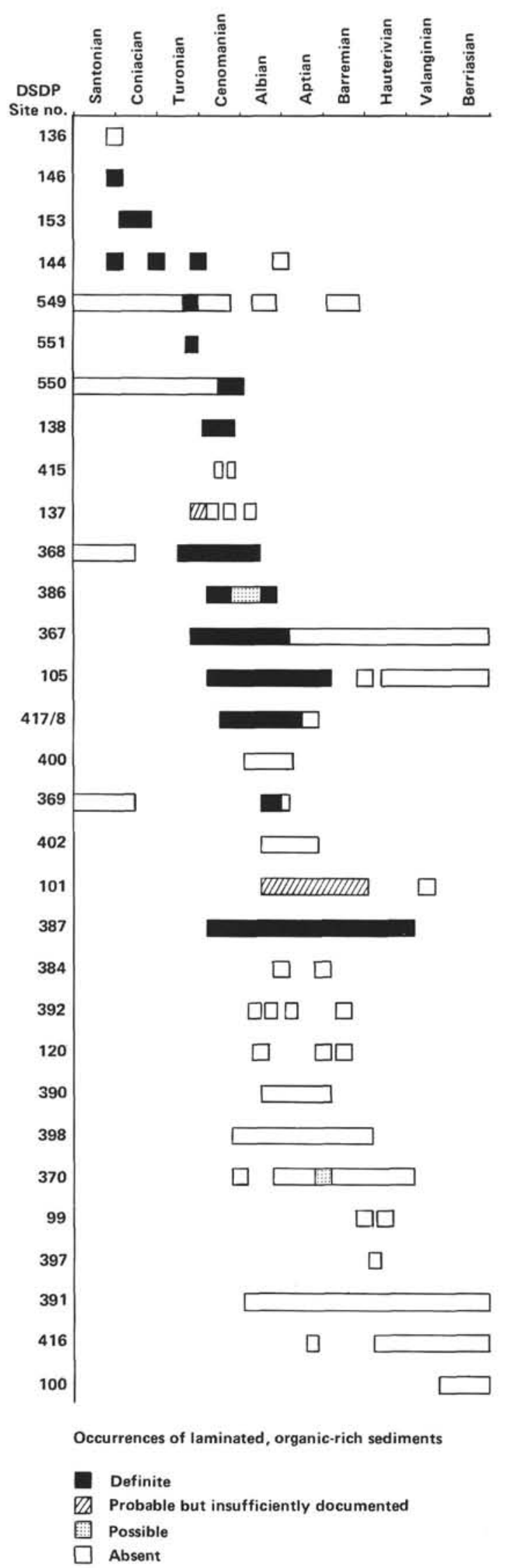

Figure 1. Occurrences of Early and middle Cretaceous sediments at DSDP sites in the North Atlantic.
Caribbean sites included in Figure 1 record anoxic sediments through Coniacian time. These results differ from those of Schlanger and Jenkyns (1976), Arthur (1979), Arthur and Schlanger (1979), and Jenkyns (1980), whose data indicated two or three modes in the distribution of black shales. Part of the discrepancy stems from uncertainties in dating (Arthur and Schlanger, 1979), and part arises from incomplete coring or poor recovery in DSDP drilling. The major reason for the discrepancy, however, is that I have employed apparently more rigorous criteria for identifying sediments deposited in anoxic waters.

The general trend of anoxia from scattered instances in the Hauterivian and Barremian, to maximum frequency in the Cenomanian-Turonian, followed by increasingly sporadic representation into early Senonian time is superficially compatible with a scenario of gradual oceanwide depletion of oxygen in the Early Cretaceous, followed by reoxygenation in the Late Cretaceous. Some difficulties with that model appear, however, when we look in more detail at individual occurrences of laminated, organic-rich sediments in the North Atlantic.

If anoxia developed in the North Atlantic by upward and downward expansion of the oxygen-minimum layer (Schlanger and Jenkyns, 1976), one would expect the earliest occurrences of sediments deposited in anoxic water to be on the outer-continental shelf or upper to middle slope, where the oxygen-minimum layer would be particularly well developed. In actuality the earliest recorded (late Hauterivian-early Barremian) anoxic sediments accumulated in deep basins below the carbonate compensation depth (DSDP Sites 101 and 387, Table 1). Evidence suggests that intermittent fluctuations in oxygen levels within the basin at Site $\mathbf{3 8 7}$ had already occurred prior to deposition of the first anoxic sediments (Tucholke et al., 1979). ${ }^{5}$ Because oxidized sediments of equivalent age are present from shallower depths at other DSDP sites (Figure 1), and because McCave (1979) has shown that no deeper water of higher oxygen content appeared to have been present near Site 387, the earliest anoxic sediments in the Cretaceous North Atlantic could not have been laid down as a result of expansion of the oxygen-minimum layer. I favor instead the model developed by Kendrick (1979) and Tucholke and Vogt (1979) of a nearly stagnant basin in which circulation was sluggish and oxygen did not reach the sea floor. Nevertheless, sedimentation at Site 387 was slow enough ( 3 to $4 \mathrm{~m} / \mathrm{m}$.y.) to permit diffusion of large amounts of sulfate into the sediments, formation of substantial amounts of pyrite, and incorporation of much sulfur into organic matter (Kendrick, 1979).

Most of the other laminated, organic-rich sediments listed in Figure 1 were deposited in deep basins with limited circulation (Sites 105, 137, 138, 367, 368, 386, and 417/8; see also Brumsack, 1980). In addition, although the water depths at the time of deposition of anoxic sediments at Sites 146 and 153 are not clearly specified,

\footnotetext{
5 In this section when no specific reference is given, the reader is referred to the site chapter in the appropriate volume of the Initial Reports of the Deep Sea Drilling Project.
} 
Table 1. Characteristics of laminated, organic-carbon-rich sediments recovered from the North Atlantic.

\begin{tabular}{|c|c|c|c|c|c|c|c|c|}
\hline $\begin{array}{l}\text { DSDP } \\
\text { site }\end{array}$ & Age & Lithology & $\begin{array}{l}\text { Depositional } \\
\text { environment }\end{array}$ & $\begin{array}{c}\text { Accumulation } \\
\text { rate } \\
(\mathrm{m} / \mathrm{m} . \mathrm{y} .)\end{array}$ & $\begin{array}{l}\text { Thickness } \\
\text { of laminated } \\
\text { zones }(\mathrm{cm})\end{array}$ & $\begin{array}{l}\text { Maximum } \\
\text { TOC }(\%)\end{array}$ & $\begin{array}{l}\text { Kerogen } \\
\text { type }\end{array}$ & References $^{\mathrm{a}}$ \\
\hline 146 & $\begin{array}{l}\text { Coniacian- } \\
\text { Santonian }\end{array}$ & $\begin{array}{l}\text { Radiolarian limestone with } \\
\text { volcanic ash, phos- } \\
\text { phate, glauconite }\end{array}$ & $\begin{array}{l}\text { Limited circulation; turbi- } \\
\text { dite influx }\end{array}$ & - & $<25$ & 11.2 & - & - \\
\hline 153 & Coniacian & $\begin{array}{l}\text { Phosphatic, calcareous, } \\
\text { and volcanic clays } \\
\text { interlayered with fora- } \\
\text { miniferal limestones }\end{array}$ & Stagnant, low area & - & $5-10$ & 6.2 & - & Bode, 1973 \\
\hline 549 & late Cenomanian & $\begin{array}{l}\text { Calcareous siliceous } \\
\text { zeolitic shale }\end{array}$ & $\begin{array}{l}\text { Middle to upper slope } \\
\text { within oxygen-mini- } \\
\text { mum layer }\end{array}$ & 3.5 & $>10$ & 3.5 & II-III & - \\
\hline 551 & $\begin{array}{l}\text { late Cenomanian- } \\
\text { early Turonian }\end{array}$ & $\begin{array}{l}\text { Siliceous zeolitic shale, } \\
\text { noncalcareous }\end{array}$ & $\begin{array}{l}\text { Lower slope within oxy- } \\
\text { gen-minimum layer }\end{array}$ & $1-2$ & $>50$ & 10.9 & II-III & - \\
\hline 550 & $\begin{array}{l}\text { latest Albian- } \\
\text { middle Ceno- } \\
\text { manian }\end{array}$ & Calcareous mudstones & $\begin{array}{l}\text { Continental rise, within } \\
\text { oxygen-minimum layer }\end{array}$ & 13 & 10 & 2.4 & II-III & - \\
\hline 137 & $\begin{array}{l}\text { late Cenomanian- } \\
\text { early Turonian }\end{array}$ & Pyritic clay & $\begin{array}{l}\text { Poorly oxygenated; } 3500 \mathrm{~m} \\
\text { in water depth; near } \\
\text { CCD }\end{array}$ & $<5$ & ? & 2 & - & $\begin{array}{l}\text { Berger and von Rad, } \\
1972\end{array}$ \\
\hline 368 & Albian-Turonian & $\begin{array}{l}\text { Slightly calcareous to } \\
\text { noncalcareous shale } \\
\text { interbedded in places } \\
\text { with sands }\end{array}$ & Deep basin, below CCD & $10 ?$ & $<10$ & 7.6 & II & Deroo et al., 1978 \\
\hline 386 & $\begin{array}{l}\text { Albian-Cenoma- } \\
\text { nian }\end{array}$ & $\begin{array}{l}\text { Black pyritic claystone } \\
\text { interlayered with radio- } \\
\text { larian sands }\end{array}$ & $\begin{array}{l}\text { Stagnant basin with nearly } \\
\text { anoxic bottom water } \\
\text { below CCD }\end{array}$ & 16 & $<50$ & 14.3 & II & Kenrick, 1979 \\
\hline 367 & $\begin{array}{l}\text { late Aptian-early } \\
\text { Turonian }\end{array}$ & $\begin{array}{l}\text { Slightly calcareous to } \\
\text { noncalcareous shale }\end{array}$ & $\begin{array}{l}\text { Deep basin with sluggish } \\
\text { circulation below } C C D\end{array}$ & 20 & $<10$ & 37.2 & I-II & $\begin{array}{l}\text { Derro et al., } 1978 \\
\quad \text { Baker et al., } \\
1978\end{array}$ \\
\hline 105 & $\begin{array}{l}\text { Barremian/ } \\
\text { Aptian- } \\
\text { Cenomanian }\end{array}$ & Zeolitic clay & Stagnant, near $C C D$ & 5 & ? & ? & - & - \\
\hline
\end{tabular}

a In addition to the DSDP site chapter.

those sediments were apparently laid down in topographic lows on a sea floor having substantial relief, rather than on a shelf or slope. Finally, the "Black Band" of England and numerous related strata in northwest Europe apparently accumulated only in topographic lows (Hart and Bigg, 1981).

Only five occurrences of laminated, organic-rich sediments were reported as possibly having been deposited in nonbasinal locations (Sites 144, 369,549, 550, and 551). Deposition at four of these locations (all but Site 369), however, occurred at the end of the anoxia maximum (middle Cenomanian to Coniacian time). Only at Site 369, where the organic-rich sediments are of early Albian age, could preservation of organic matter possibly be related to the initial expansion of the oxygenminimum layer.

Evidence from most of the examples cited above, as well as from cores from the Pacific and Tethyan oceans (Dean, Claypool, et al., 1981; Weissert et al., 1979) suggests that anoxia was not maintained for long intervals.
The stratigraphic record at several locations (Sites 367, $368,386,387$, and 550 ) shows that intermittent fluctuations of oxygen levels in the bottom waters preceded and succeeded complete anoxia; it also shows that bottom water conditions alternated between anoxic and oxic during the overall interval in which black, laminated, organic-rich sediments accumulated. Laminated, organicrich sediments are interbedded with burrowed, light-colored sediments laid down under bottom-water conditions that were significantly more oxygenated. Laminated intervals rarely exceed $10 \mathrm{~cm}$ in thickness (Table 1) (Dean, personal communication, 1982).

Fluctuations in productivity may have been responsible for the observed depositional cycles at Sites 367 and 368 (Dean et al., 1978; Gardner et al., 1978). If anoxia induced by high productivity was normal at these sites and if the North Atlantic as a whole was severely depleted in oxygen at this time, it is difficult to understand how a brief local decrease in organic productivity could lead to development of oxic bottom waters. Since pro- 


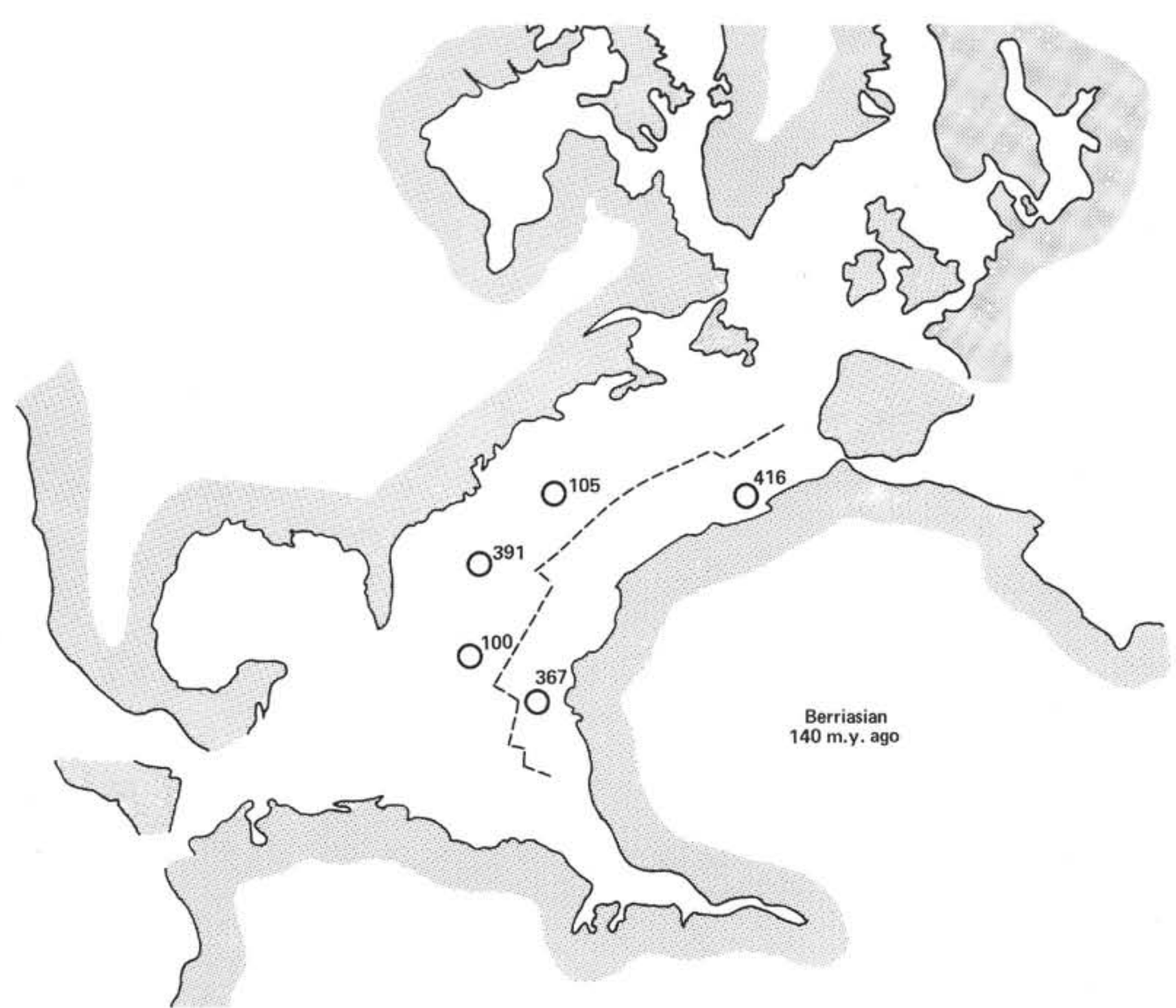

Figure 2. Occurrences of sediments of Berriasian (Early Cretaceous) age at DSDP sites in the North Atlantic. Open circles indicate an absence of laminated, organic-carbon-rich sediments. Dashed line shows mid-oceanic ridge.

ductivity changes were able to cause oxic-anoxic depositional cycles at Sites 367 and 368, the North Atlantic was most likely not severely depleted in oxygen during much of Albian-Turonian time.

The rapid and cyclical alternation of oxic and anoxic conditions in bottom waters at all these sites is most consistent with a model characterized by a delicate balance of water exchange between relatively isolated, oxygen-poor basins and the surrounding oxygenated ocean. Changes in circulation rates and fluctuations in productivity both altered oxygen supply and demand. These effects were probably local in nature, however, because oxygen levels in the entire proto-North Atlantic could not have fluctuated rapidly enough to cause such alternations, especially in basinal settings where response to global changes would have been slower than in the open ocean.

Productivity may have been the principal factor that determined oxygen levels in bottom waters at some locations, specifically Sites 138 (Berger and von Rad, 1972), 387 (Kendrick, 1979), and 549, 550, and 551 (Waples and Cunningham, this volume). Sites 549, 550, and 551 are particularly interesting (Figure 7); during the Cretaceous they were all located on topographic highs and therefore do not represent accumulations in stagnant basins. The laminated, black, calcareous sediments of late Cenomanian or earliest Turonian age at Sites 549 and
551 contain $3.5 \%$ and $8-11 \%$ TOC, respectively, whereas possibly coeval homogeneous or burrowed black clays at Site 550 average about $0.5 \%$ TOC. Site 549 lay on the upper to middle slope in upper to middle bathyal water depths, Site 551 was lower bathyal, and Site 550 was abyssal.

The organic-rich sediments at Sites 549 and 551 are both highly siliceous, with little or no carbonate. These lithologies contrast sharply with the over- and underlying strata, which are highly calcareous and generally nonsiliceous. They also differ from the noncalcareous, nonsiliceous black clay at Site 550. The silica is biogenic and is most likely the consequence of periods of high productivity.

\section{MODEL FOR THE GOBAN SPUR REGION, NORTH ATLANTIC}

I propose the model shown in Figure 8 to explain the black sediments of Cenomanian to earliest Turonian age at ine three sites. During Albian and earliest Cenomanian time the waters were well oxygenated, and a modest nutrient supply supported a moderate quantity of calcareous phytoplankton. Commencing in the middle Albian, occasional local upwellings resulted in increased nutrient availability near Site 549 , leading to brief interludes of dominance by siliceous organisms. These events are recorded as thin beds of siliceous sediments observed 


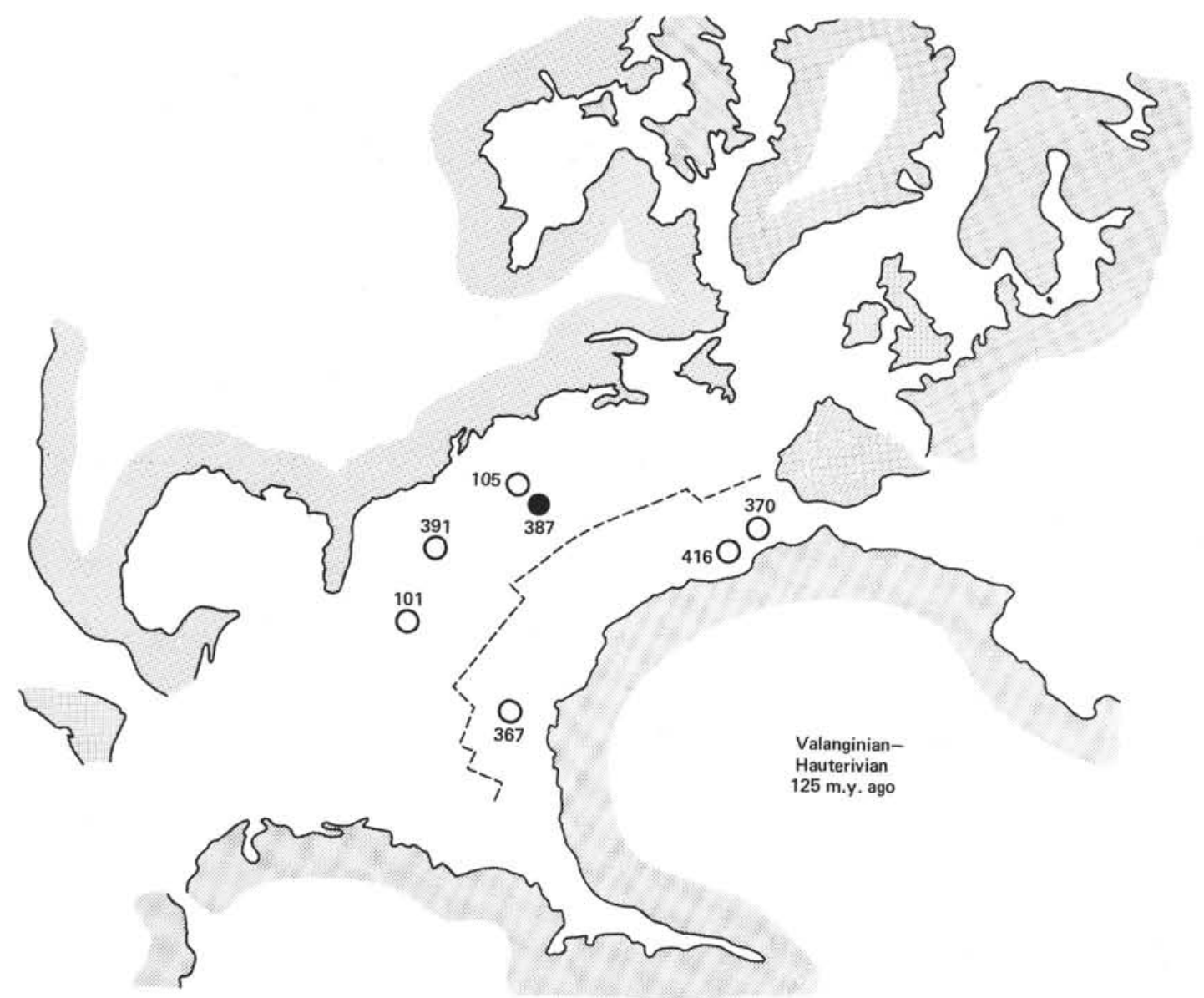

Figure 3. Occurrences of sediments of Valanginian-Hauterivian (Early Cretaceous) age at DSDP sites in the North Atlantic. Dark circles indicate the presence of some laminated, organic-carbon-rich sediments; open circles indicate an absence of such sediments. Dashed line shows mid-oceanic ridge.

within the calcareous facies (Figure 8A). Oxygen supply at this time apparently continued to exceed demand, however, because no evidence exists for preservation of unusually large quantities of organic matter during these blooms.

In the early Cenomanian, however, oxygen contents of the waters at Site 550 had apparently diminished significantly, leading to numerous brief episodes of organic enrichment (up to $2.4 \%$ TOC) under anoxic or nearly anoxic conditions. De Graciansky and Gillot (this volume) have suggested that fluctuations in the vigor of bottom currents were responsible for the alternating accumulation of oxic and anoxic sediments at Site 550 (Figure 9). The scarcity of biogenic silica at this time indicates that early and middle Cenomanian anoxia was not related to increased productivity but rather that Site 549 lay on a well-oxygenated shelf (Figure $8 \mathrm{~B}$ ) which accumulated only oxic sediments. No sediments as old as middle or early Cenomanian were found at Site 551, but it is possible that they may underlie basalt that was not fully penetrated (Figure 7).

According to this model, by late Cenomanian time water depth had increased, the oxygen-minimum layer had expanded in response to increased biological productivity, and laminated, organic-rich sediments had been deposited at Sites 549 and 551 (Figure 8C). Site 550 probably lay outside the zone of highest productivity, as indicated by a lack of silica in sediments from this site. Dilution by biogenic silica is responsible for the low calcite contents of Site 549 sediments but cannot explain the complete absence of carbonate at Sites 550 and 551 . These latter two sites probably lay below a very high carbonate compensation depth (CCD).

The organic-carbon contents directly reflect these histories. Site 549, which during the time of deposition of organic-carbon-rich sediments was apparently near the upper end of the oxygen-minimum zone, has a relatively low organic-carbon content $(3.5 \%)$ for a laminated sediment. The intense anoxia at Site 551 resulted in preservation of large amounts of organic carbon ( $8-11 \%$ TOC) of partly marine origin. Site 550 lay near the lower end of the oyxgen-minimum layer, but because of its very low sediment accumulation rate (Site 550 chapter, this volume) apparently caused by the combined effects of carbonate dissolution, low detrital input, and possible lower productivity in the overlying photic zone, the bottom waters were unable to remain anoxic. Black clays grading upward into green, olive, light gray, and finally red clays trace the gradual invasion of oxygen into the bottom of the oxygen-minimum layer.

The end of anoxia at Sites 549 and 551 coincided with the disappearance of siliceous sediments, and there- 


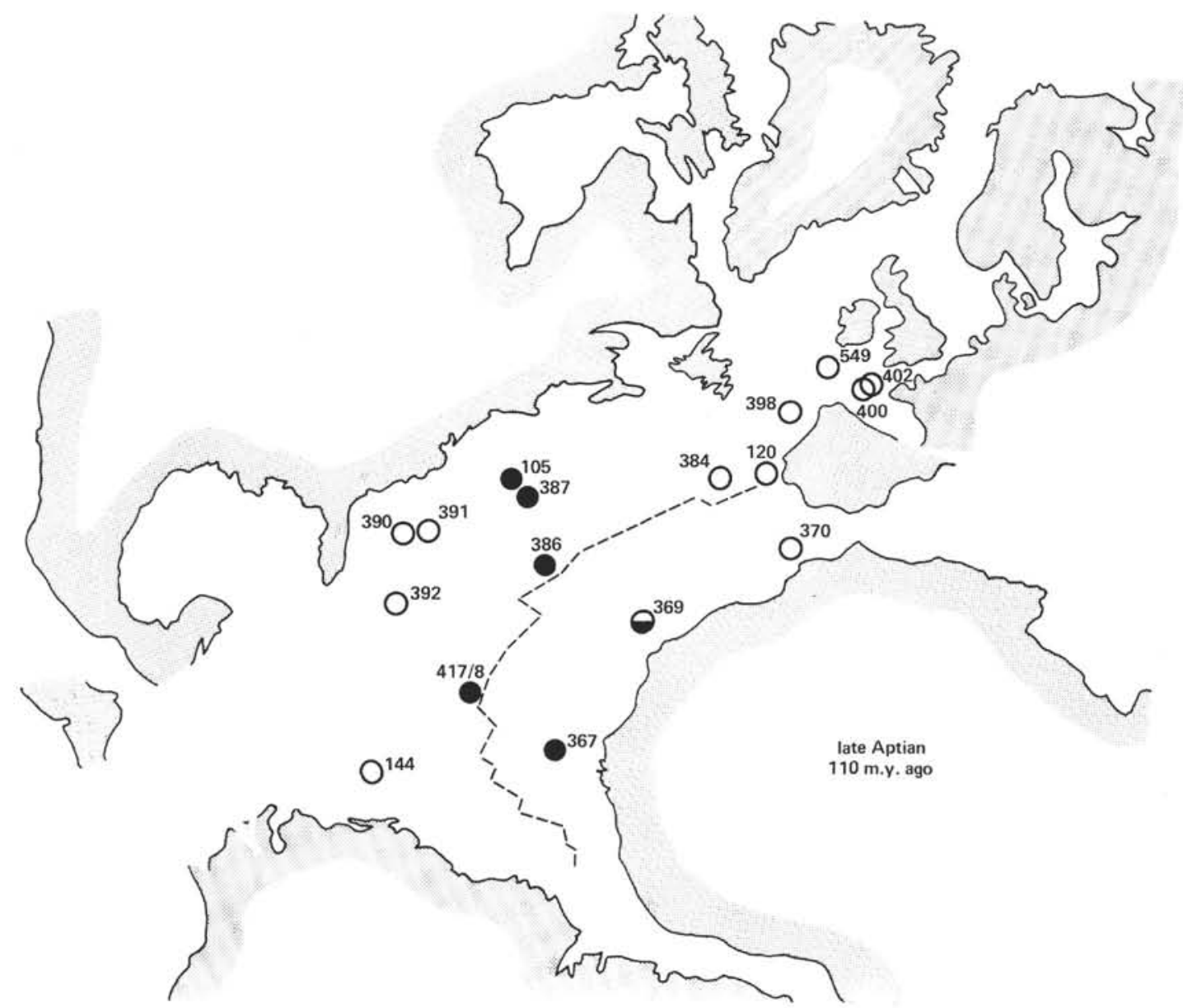

Figure 4. Occurrences of sediments of late Aptian (Early Cretaceous) age at DSDP sites in the North Atlantic. Symbols as in Figure 3.

fore may have been primarily a result of decreased productivity (Figure 8D). Increased circulation, as evidenced by hiatuses postdating the early Turonian at Sites 550 and 551, as well as at numerous other DSDP sites (including 400, 401, and 402 in the Bay of Biscay [Montadert, Roberts, et al., 1979]) probably also played a role in raising oxygen levels (de Graciansky and Gillot, this volume). Although a hiatus is not recognized at Site 549 , a significant lowering of the sediment accumulation rate also suggests increased current activity. These apparent changes in currents may also have been responsible for decreasing productivity by shifting the loci of upwellings.

It is probably not coincidental that the CCD rose at the same time that sediments rich in organic matter were accumulating in many locations in the North Atlantic. One possible explanation for the relationship between organic-carbon richness and elevated CCD is that recycling of organic carbon represents an important source of carbonate in deep waters. When recycling is inhibited by organic preservation, deep waters become undersaturated with respect to calcium carbonate and become corrosive (Figure 10). The CCD will therefore rise (Figure 10B). As it rises, however, sediment accumulation rates below the CCD decline, and preservation of organic matter consequently decreases. As oxidation of organic carbon in the deeper waters supplies more carbonate, the CCD will eventually cease rising and begin to fall (Figure 10C). This cyclic process apparently occurred throughout most of the North Atlantic during Cenomanian and Turonian time as evidenced by the absence of carbonate in all but the shallowest organic-carbon-rich sediments of those ages (Table 1).

In summary, although there was a gradual increase in occurrence of anoxia in the North Atlantic beginning in about Aptian time, most of these early occurrences of anoxic waters were in deep basins and therefore do not indicate that the North Atlantic was suffering from a general oxygen deficiency. The numerous sites in which oxic sediments of Aptian and Albian age have been recovered from the North Atlantic (Figure 1) are evidence that a permanent expanded oxygen-minimum layer was not yet important.

By early Cenomanian time, however, the oxygen-minimum layer had begun to expand, resulting in widespread but sporadic deposition of anoxic sediments throughout the late Cenomanian. The elevation of the CCD that accompanied preservation of large amounts of organic 


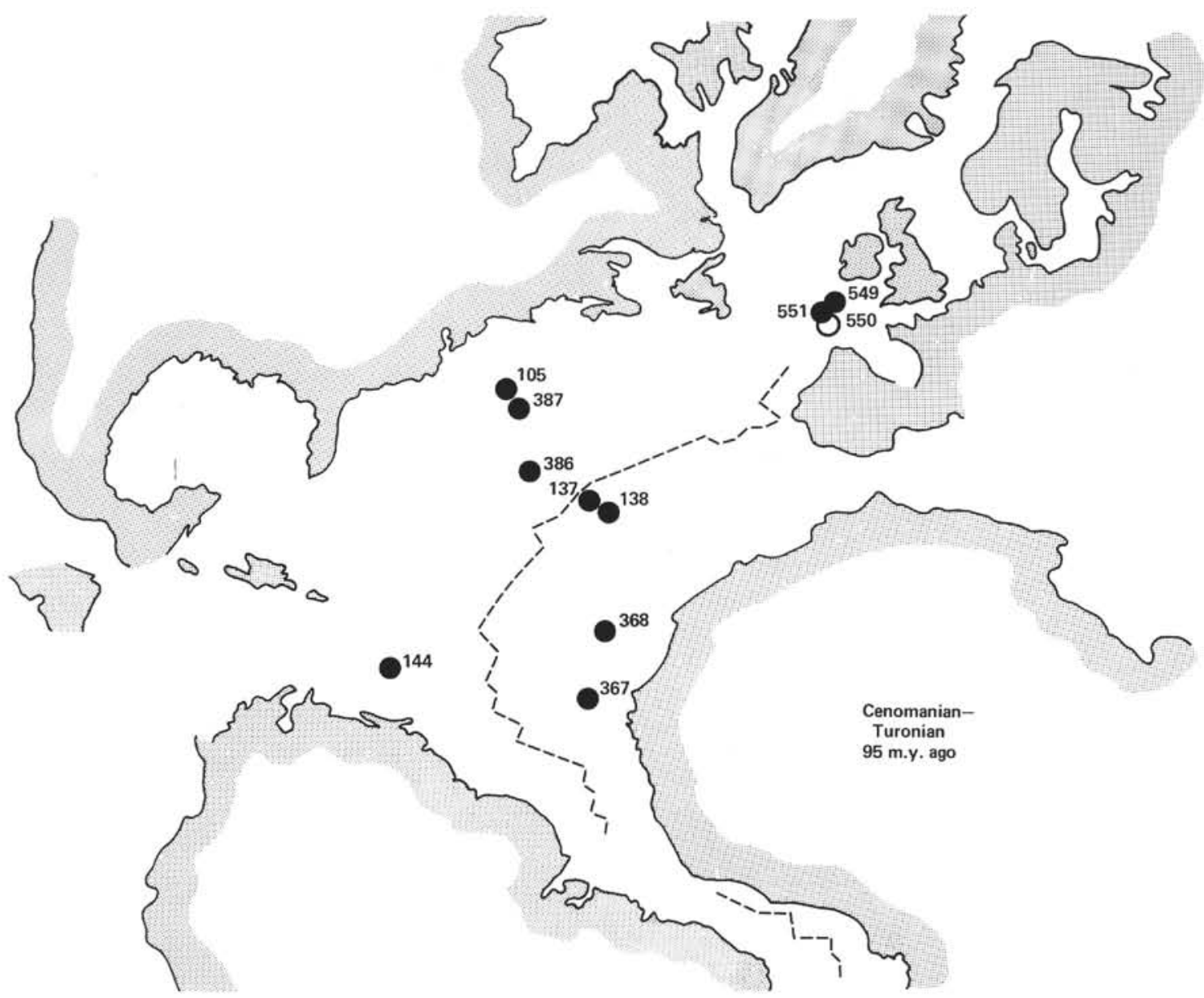

Figure 5. Occurrences of sediments of Cenomanian-Turonian (Late Cretaceous) age at DSDP sites in the North Atlantic. Symbols as in Figure 3.

carbon apparently also slowed accumulation rates through carbonate dissolution and helped put an end to the anoxic episode in the North Atlantic by Coniacian time.

\section{FACTORS AFFECTING OXYGEN LEVELS IN THE CRETACEOUS NORTH ATLANTIC}

If oxygen levels throughout the North Atlantic were in fact low during mid-Cretaceous, what could have been the causes? Numerous ideas have been put forth and eloquently defended, including restricted circulation because of unfavorable continental geometries (Berggren and Hollister, 1977); presence of mid-oceanic submarine ridges (Tissot et al., 1979; Ryan and Cita, 1977); proliferation of tectonically controlled basins (Arthur and Schlanger, 1979); lack of circumpolar currents (Schnitker, 1980); climatic effects (Berggren and Hollister, 1977; Hays and Pitman, 1973; Fischer and Arthur, 1977; Brumsack, 1980; Arthur and Schlanger, 1979; Kennett, 1977); injection of anoxic water from the South Atlantic (Thierstein and Berger, 1978) or from shallow salty shelves (Hay, 1982); inundation of oceans with terrestrial organic matter as a combined result of transgression and proliferation of angiosperms (Jenkyns, 1980); and unusually high marine productivity (Arthur and Schlanger, 1979). The arguments based on paleoceanography and plate tectonics seem plausible, given the limits of our ability to reconstruct precisely the geographies and geometries of the Cretaceous, and will not be considered here.

\section{Transgressions}

The transgressions of the Cretaceous have been proposed as important in fostering marine anoxia because they inundated forested areas and thus introduced great quantities of woody debris into the oceans (Jenkyns, 1980). I do not agree with these conclusions. A marine incursion that kills a tree adds a single tree's worth of wood to the marine environment, whereas if not flooded, the same patch of land that grew the tree could potentially produce half a million or more trees over a $30-$ m.y. period. Even assuming that most of the resultant dead wood in the latter case was decayed in situ and never reached the ocean, the total amount of wood available to the marine realm (via rivers) would have been several orders of magnitude greater if transgression had not occurred.

Furthermore, the rate of Cretaceous transgression, although probably rapid in geologic terms, was still far too slow to have been catastrophic. Even the Late Cretaceous transgressions in the Western Interior of the United States advanced at a maximum average rate of less than $60 \mathrm{~cm}$ per year (Hancock and Kauffman, 1979). 


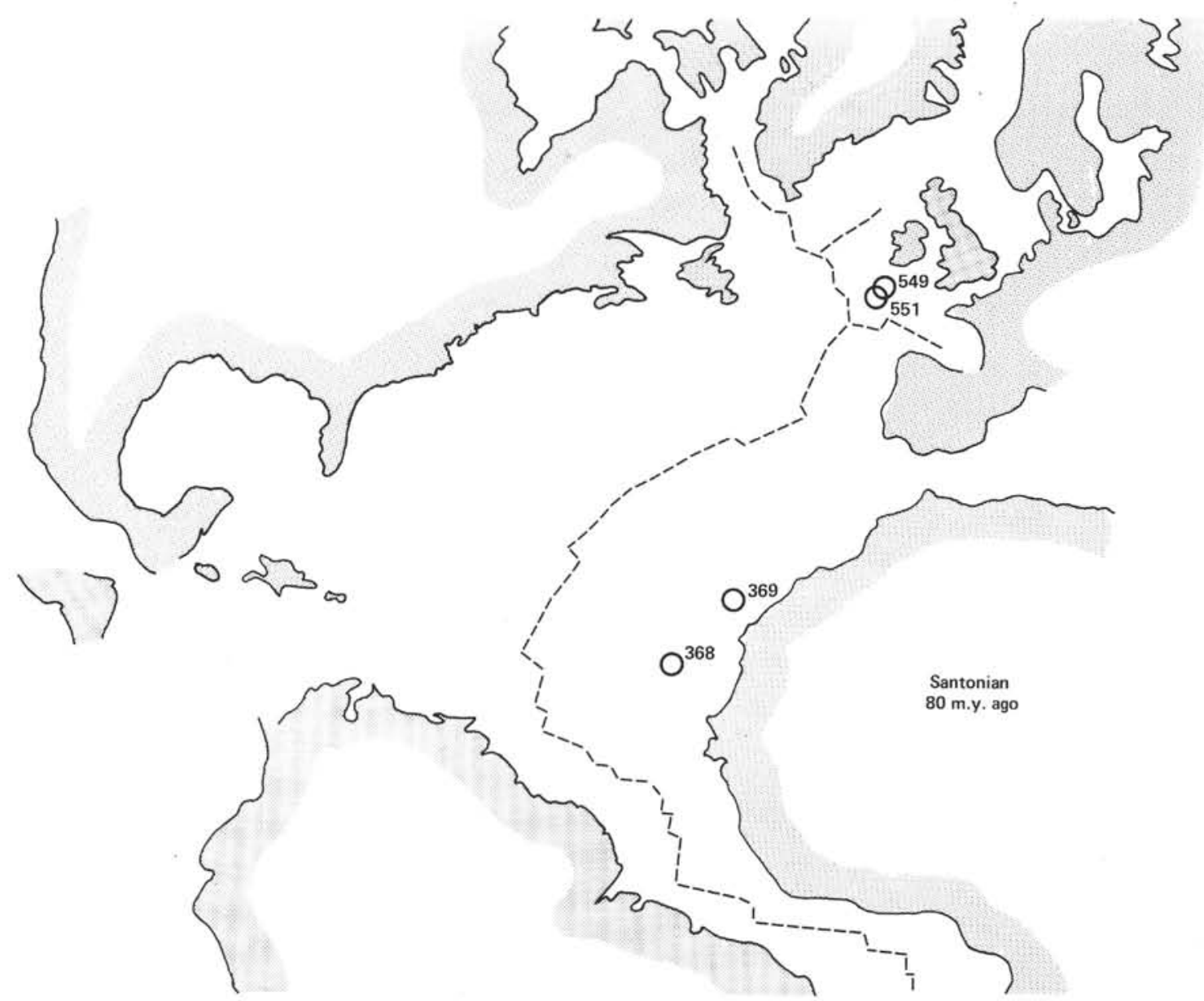

Figure 6. Occurrences of sediments of Santonian (Late Cretaceous) age at DSDP sites in the North Atlantic. Symbols as in Figure 3.

Furthermore, given the low oxygen demand of terrestrial organic matter in general and woody material in particular, it is far from certain that a minor increase in the influx of such material would appreciably alter the oxygen content of the ocean. Most of it would probably be buried relatively intact, with little or no depletion of dissolved oxygen in the ocean.

\section{Marine Productivity}

Marine productivity is thought by many to have been high during the Cretaceous, particularly in the Cenomanian (Summerhayes, 1981; Hart and Bigg, 1981). Extensive chalk deposition and evidence for bottom-water anoxia have been used to support this contention. However, the Cretaceous was more likely a time of moderate to low productivity (Ryan and Cita, 1977; Bralower and Thierstein, 1982) on the basis of both sediment accumulation rates and geochemical and lithologic evidence from Cretaceous sediments. Cases in which anoxia is linked to productivity are exceptional.

Jenkyns (1980) cites the studies of Håkansson et al. (1974) of Maestrichtian chalks deposited on a continental shelf as being indicative of high productivity during the Cretaceous. Although the calculated sediment accumulation rates of Håkansson and co-workers of $150 \mathrm{~m}$ / m.y. are extreme for biogenic calcareous sediments, they are irrelevant to our discussion because the Maestrichtian is much younger than the stages associated with anoxia. Furthermore, inasmuch as no organic-rich layers are associated with those Maestrichtian chalks, those shelf waters must have been well aerated to have oxidized the large amounts of organic matter produced by phytoplankton. Finally, sediment accumulation rates are usually 15 to 50 times slower for Early and middle Cretaceous chalks than for the Maestrichtian examples of Håkansson and co-workers. The accumulation rates of the black, laminated, organic-rich facies calculated by DSDP workers are typically 3 to $10 \mathrm{~m} / \mathrm{m}$.y. (Table 1 ). In a few exceptional cases where resedimentation by turbidites played a major role, the overall rate reached $20 \mathrm{~m} / \mathrm{m}$.y., but the biogenic component was deposited at a much slower rate. There is to my knowledge no documentation of Early or middle Cretaceous chalks that accumulated at high rates.

The modest accumulation rates of biogenic material during Early and middle Cretaceous time contrast strikingly with accumulation rates in areas of high productivity from both ancient and modern settings. The Monterey and Sisquoc Formations of California (MiocenePliocene), for example, contain highly siliceous rocks derived mainly from diatoms that thrived in a fecund upwelling zone. Accumulation rates were typically 50- 


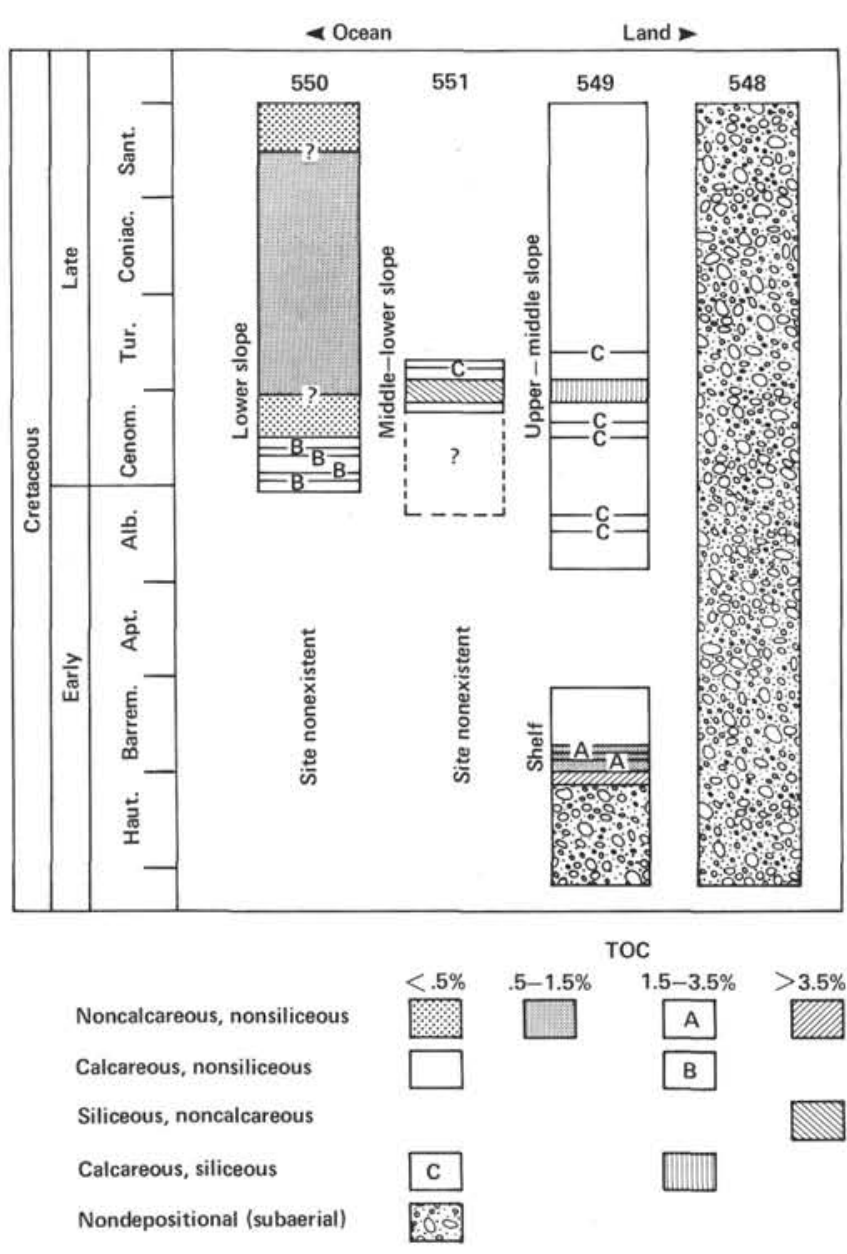

Figure 7. Lithologic logs for Early and middle Cretaceous sediments from DSDP sites, Goban Spur, North Atlantic Ocean.

200 m/m.y. (Graham, 1976; Ingle, 1980). Rates of accumulation of modern diatomaceous sediments in the Gulf of California are $5000 \mathrm{~m} / \mathrm{m}$.y. (Calvert, 1966). Off the Namibian coast (Southwest Africa) and off the coast of Peru, accumulation rates for biogenic siliceous sediments are $150-1000$ and $1000 \mathrm{~m} / \mathrm{m}$.y., respectively (Veeh et al., 1974; Suess, 1981).

High sediment accumulation rates foster preservation of organic matter (Müller and Suess, 1979; Gorsline, 1981; Ibach, 1982; Habib, 1982). Accumulation rates for laminated, organic-rich sediments of Early and middle Cretaceous age, however, are much lower than the optimal rates for organic preservation. This discrepancy may indicate that the longer residence time of the midCretaceous North Atlantic sediments in the zone of microbial diagenesis was compensated by very low oxygen levels in bottom waters.

The general scarcity of silica in Cretaceous sediments of the North Atlantic may also be indicative of low productivity because zones of high productivity in modern oceans are invariably rich in diatoms, radiolaria, or both (Lisitzin, 1971; Garrison, 1981). Siliceous organisms were probably also associated with highly productive waters even during the Early Cretaceous, because the one site of well-preserved Albian-aged diatoms is a phosphorite deposit near Hannover (Jousé, 1978). Phosphorites are commonly linked to high productivity (Baturin and $\mathrm{Be}-$ zrukov, 1979). The lack of recognizable diatoms in siliceous sediments predating Late Cretaceous time may be a result of the susceptibility of diatoms to diagenetic transformation. Intensive evolution of diatoms had apparently already occurred in the Early Cretaceous (Jousé, 1978; Garrison, 1981).

Finally, there is no clear correlation in modern oceans between productivity and preservation of organic material (Demaison and Moore, 1980; Demaison, 1981). Sedimentary processes and nonseasonal variations in currents may well be more important than upwelling (and its consequent high productivity) in determining the input of organic matter to sediments (Heath et al., 1977; Douglas, 1981).

In light of these data, it is difficult to view the Cretaceous North Atlantic as a fertile area. Neither transgressions nor heightened productivity during the Cretaceous is a viable explanation for the low oxygen levels in bottom waters of the middle Cretaceous North Atlantic; the cause is more likely the oceanographic or topographic factors cited earlier.

\section{SUMMARY}

The hypothesis of global or oceanic anoxia during much of Early and middle Cretaceous time is not supported by available evidence. In testing the hypothesis it was first necessary to define clearly the types of sediments deposited under anoxic conditions. Previous criteria were rejected in favor of new criteria requiring that such sediments not only be highly enriched in organic matter but that they also show evidence of deposition in the absence of oxygen.

Occurrences of anoxic sediments in the Cretaceous Pacific Ocean seem to be better explained as a result of local conditions than of global anoxia. The South Atlantic appears to have been largely anoxic during the Early and middle Cretaceous, but it apparently was a much smaller feature than it is today and was in poor communication with other bodies of water. As a result its sedimentary record is probably not useful as an indicator of oxygen levels in other oceans. Occurrences of black, laminated, organic-rich sediments of Early and middle Cretaceous age from the North Atlantic indicate that anoxia occurred most commonly in deep basins as a result of sluggish circulation. Deposition of anoxic sediments on the shelf and upper slope was less frequent. The distribution of anoxic sediments through time and space suggests that they initially formed in isolated basins as a result of topographic control of circulation patterns. Topography in turn was probably strongly influenced by continental drift after the breakup of Pangea and by rotation of Iberia, which closed the TethysNorth Atlantic passage (North, 1980), as well as by extensive subsea volcanism.

Subsequently, an expanded oxygen-minimum layer developed in the late Cenomanian to early Turonian, a time interval which also appears to have been associated with an upward migration of the CCD. During this time, extensive deposition of laminated organic-rich sediments occurred both on the continental slope and in restricted basins. Low accumulation rates are compatible with ex- 
A

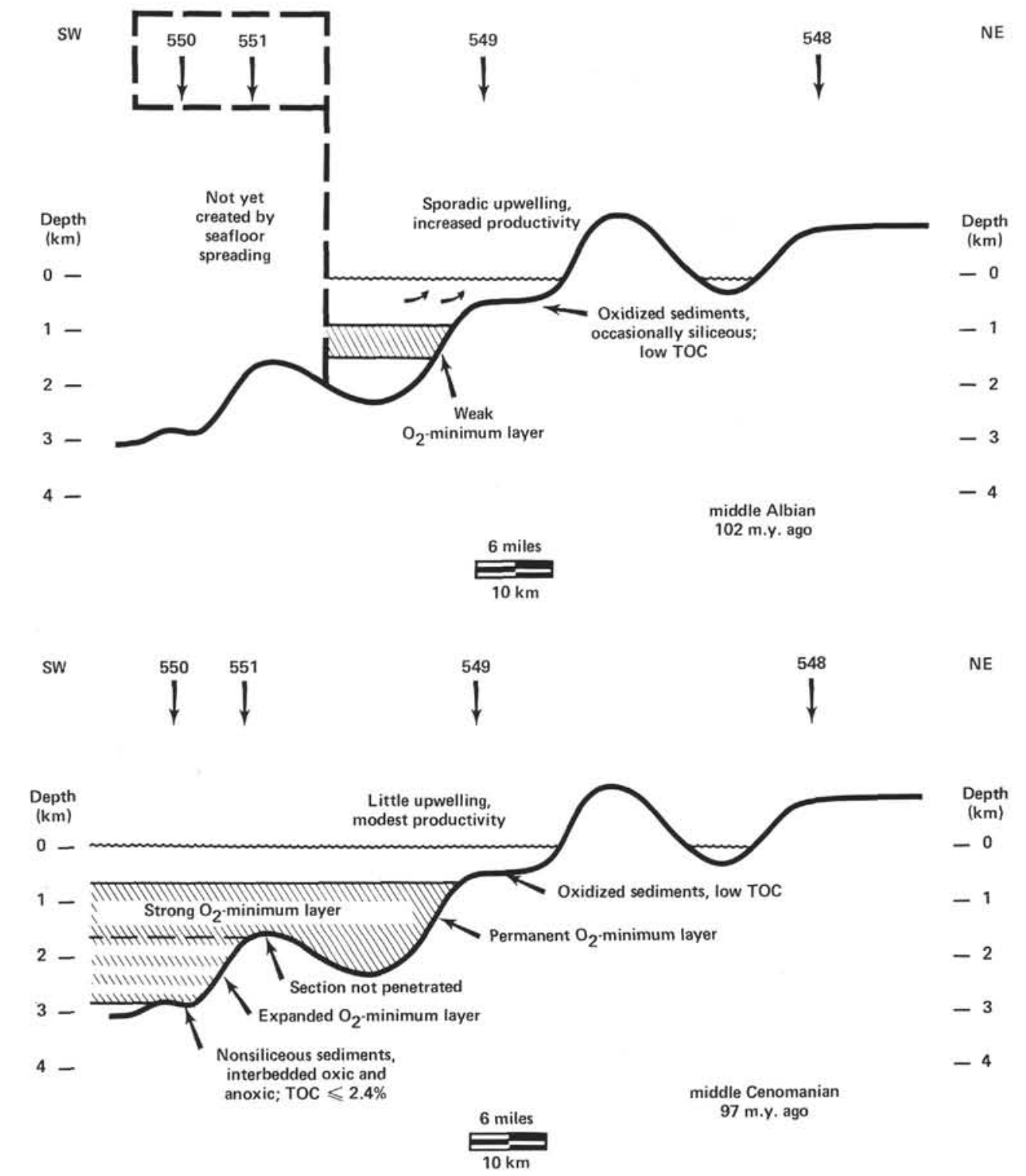

Figure 8. Schematic representation of mid-Cretaceous depositional environments along the Leg 80 transect (A-D as explained in text).

treme oxygen depletion. The anoxic interval terminated when improved circulation and a high CCD combined to promote oxidation of sedimentary organic matter in the deep oceans.

Upwelling and high productivity may occasionally have been important or contributory to anoxia but are probably of secondary importance.

\section{ACKNOWLEDGMENTS}

I thank my shipboard colleagues for stimulating discussions; Doug Kirkland, Pierre Charles de Graciansky, and Keith Kvenvolden for many helpful comments in reviewing the manuscript, Bunny Cummins for typing the manuscript, and Mobil Research and Development Corporation for permission to publish this work.

\section{REFERENCES}

Addy, S. K., and Behrens, E. W., 1980. Time of accumulation of hypersaline anoxic brine in Orca Basin (Gulf of Mexico). Mar. Geol., $37: 241-252$.
Arthur, M. A., 1979. North Atlantic Cretaceous black shales: The record at Site 398 and a brief comparison with other occurrences. In Sibuet, J.-C., and Ryan, W. B. F., et al. Init. Repts. DSDP, 47, Pt. 2: Washington (U.S. Govt. Printing Office), 719-751.

Arthur, M. A., and Natland, J. H., 1979. Carbonaceous sediments in the North and South Atlantic: The role of salinity in stable stratification of Early Cretaceous basins, In Talwani, M., Hay, W., and Ryan, W. B. F. (Eds.), Deep Drilling Results in the Atlantic Ocean: Continental Margins and Paleoenvironment. Washington (American Geophysical Union), 375-401.

Arthur, M. A., and Schlanger, S. O., 1979. Cretaceous "oceanic anoxic events" as causal factors in development of reef-reservoired giant oil fields. Bull. Am. Assoc. Petr. Geol., 63:870-885.

Baker, E. W., Huang, W. Y., Rankin, J. G., Castaño, J. R., Guinn, J. R., and Fuex, A. N., 1978. Electron paramagnetic resonance study of thermal alteration of kerogen in deep-sea sediments by basaltic sill intrusion. In Lancelot, Y., Seibold, E., et al., Init. Repts. DSDP, 41: Washington (U.S. Govt. Printing Office), 839-847.

Baturin, G. N., and Bezrukov, P. L., 1979. Phosphorites on the sea floor and their origin. Mar. Geol., 31:317-332.

Berger, W. H., and von Rad, U., 1972. Cretaceous and Cenozoic sediments from the Atlantic Ocean. In Hayes, D. E., Pimm, A. C., et 


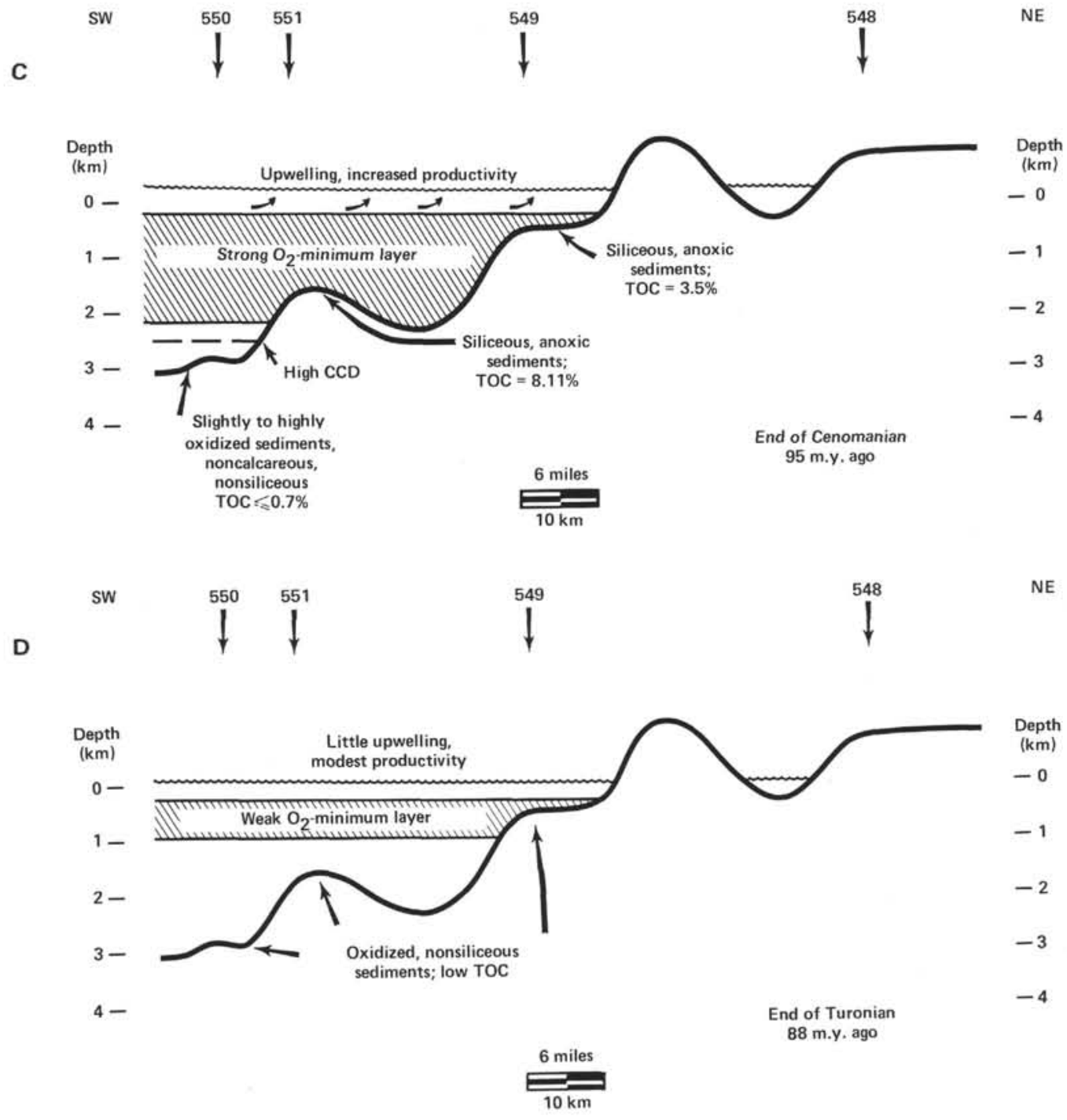

Figure 8. (Continued).

al., Init. Repts. DSDP, 14: Washington (U.S. Govt. Printing Office), 787-954.

Berggren, W. A., and Hollister, C. D., 1977. Plate tectonics and paleocirculation-commotion in the ocean. Tectonophysics, 38:11-48.

Bernoulli, D., and Jenkyns, H. C., 1974. Alpine, Mediterranean and central Atlantic Mesozoic facies in relation to the early evolution of the Tethys. In Dott, R. H., and Shaver, R. H. (Eds.), Modern and Ancient Geosynclinal Sedimentation. Soc. Econ. Paleontol. Mineral Spec. Publ., 19:129-160.

Bode, G. W., 1973. Appendix II: Carbon and carbonate analyses, Leg 15. In Edgar, N. T., Saunders, J. B., et al., Init. Repts. DSDP, 15: Washington (U.S. Govt. Printing Office), 1129-1137.

Bralower, T., and Thierstein, H. R., 1982. Mid-Cretaceous black shales: A result of excessive fertility or global anoxia? Bull. Am. Assoc. Petr. Geol., 66:552.

Brumsack, H.-J., 1980. Geochemistry of Cretaceous black shales from the Atlantic Ocean (DSDP Legs 11, 14, 36 and 41). Chem. Geol., 31:1-25.

Calvert, S. E., 1966. Accumulation of diatomaceous silica in the sediments of the Gulf of California. Bull. Geol. Soc. Am., 77:569-596.

Davies, T. A., Luyendyk, B. P., et al., 1974. Site 258. In Davies, T. A., Luyendyk, B. P., et al., Init. Repts. DSDP, 26: Washington (U.S. Govt. Printing Office), 359-414.

Dean, W. E., Barron, E. J., and Boyce, R. E., 1981. A Cretaceous black-shale deposition within an oxidized red clay, turbidite environment, southern Angola Basin, South Atlantic Ocean. Bull. Am. Assoc. Petr. Geol., 65:917.
Dean, W. E., Claypool, G. E., and Thiede, J., 1981. Origin of organic-carbon-rich mid-Cretaceous limestones, mid-Pacific mountains, and southern Hess Rise. In Thiede, J., Vallier, T. L., et al., Init. Repts. DSDP, 62: Washington (U.S. Govt. Printing Office), 877-890.

Dean, W. E., Gardner, J. V., Jansa, L. F., Čepek, P., and Seibold, E., 1978. Cyclic sedimentation along the continental margin of northwest Africa. In Lancelot, Y., Seibold, E., et al., Init. Repts. DSDP, 41: Washington (U.S. Govt. Printing Office), 965-989.

de Graciansky, P. C., et al., 1982. Les formations d'âge Crétacé de l'Atlantique Nord et leur matière organique: paléogéographie et milieux de dépôt. Rev. Inst. Franc. Petr., 37:275-337.

Demaison, G. J., 1981. Oil source bed deposition and occurrence on active continental margins. In Douglas, R. G., Colburn, I. P., and Gorsline, D. S. (Eds.), Depositional Systems of Active Continental Margin Basins: Short Course Notes. Soc. Econ. Paleontol. Mineral. Pacific Section, pp. 157-165.

Demaison, G. J., and Moore, G. T., 1980. Anoxic environments and oil source bed genesis. Org. Geochem., 2:9-31.

Deroo, G., Herbin, J. P., Roucaché, J., Tissot, B., and Albrecht, P., 1978. Organic geochemistry of some Cretaceous black shales from Sites 367 and 368: Leg 41, eastern North Atlantic. In Lancelot, Y., Seibold, E., et al., Init. Repts. DSDP, 41: Washington (U.S. Govt. Printing Office), 865-873.

Deroo, G., Herbin, J. P., Roucaché, J., and Tissot, B., 1980. Organic geochemistry of Cretaceous sediments at DSDP holes 417D (Leg 51), 418A (Leg 52), and 418B (Leg 53) in the western North Atlan- 
tic. In Donnelly, T., Francheteau, J., Bryan, W., Robinson, P., Flower, M., Salisbury, M., et al., Init. Repts. DSDP, 51, 52, 53, Pt. 2: Washington (U.S. Govt. Printing Office), 737-745.

Douglas, R. G., 1981. Paleoecology of continental margin basins: A modern case history from the Borderland of Southern California. In Douglas, R. G., Colburn, I. P., and Gorsline, D. S. (Eds.), Depositional Systems of Active Continental Margin Basins: Short Course Notes. Soc. Econ. Paleontol. Mineral. Pacific Section, pp. 121-156.

Emery, K. O., 1960. The Sea off Southern California: New York (John Wiley).

Evans, R., 1978. Origin and significance of evaporites in basins around Atlantic margin. Bull. Am. Assoc. Petr. Geol., 62:223-234.

Fischer, A. G., and Arthur, M. A., 1977. Secular variations in the pelagic realm. In Cook, H. E., and Enos, P. (Eds.), Deep Water Carbonate Environments. Soc. Econ. Paleontol. Mineral. Spec. Publ., 25:19-50.

Gardner, J. V., Dean, W. E., and Jansa, L., 1978, Sediments recovered from the northwest African continental margin, Leg 41, Deep Sea Drilling Project. In Lancelot, Y., Seibold, E., et al., Init. Repts. DSDP, 41: Washington (U.S. Govt. Printing Office), 1121-1134.

Garrison, R. E., 1981. Pelagic and hemipelagic sedimentation in active margin basins. In Douglas, R. G., Colburn, I. P., and Gorsline, D. S. (Eds.), Depositional Systems of Active Continental Margin Basins: Short Course Notes. Soc. Econ. Paleontol. Mineral. Pacific Section, pp. 15-38.

Gorsline, D. S., 1981. Fine sediment transport and deposition in active margin basins. In Douglas, R. G., Colburn, I. P., and Gorsline, D. S. (Eds.), Depositional Systems of Active Continental Margin Basins: Short Course Notes. Soc. Econ. Paleontol. Mineral. Pacific Section, pp. 39-59.

Graham, S. A., 1976. Tertiary sedimentary tectonics of the central Salinian block of California [Ph.D. dissert.]. Stanford University, Palo Alto.

Habib, D., 1982. Sedimentation of black clay organic facies in a Mesozoic oxic North Atlantic. Proc. Third North American Paleontological Convention, 1:217-220.

Håkansson, E. Bromley, R. G., and Perch-Nielsen, K., 1974. Maastrichtian chalk of north-west Europe-a pelagic shelf sediment. In Hsü, K. J., and Jenkyns, H. C. (Eds.), Pelagic Sediments: On Land and under the Sea. Spec. Publ. Int. Assoc. Sediment., 1: 211-233.

Hancock, J. M., and Kauffman, E. G., 1979. The great transgressions of the Late Cretaceous. J. Geol. Soc. (London), 136:175-186.

Hart, M. B., and Bigg, P. J., 1981. Anoxic events in the Late Cretaceous chalk seas of North-west Europe, I.G.C.P. Project, 58: $177-185$.

Hay, W. W., 1982. Mesozoic paleo-oceanography of Atlantic and Western Interior Seaway. Bull. Am. Assoc. Petr. Geol., 66:579.

Hays, J. D., and Pitman, W. C., III, 1973. Lithospheric plate motion, sea level changes, and climatic and geological consequences. $\mathrm{Na}$ ture (London), 246:18-22.

Heath, G. R., Moore, T. C., Jr., and Dauphin, J. P., 1977. Organic carbon in deep-sea sediments. In Andersen, N. R., and Malahoff, A. (Eds.), The Fate of Fossil Fuel $\mathrm{CO}_{2}$ in the Oceans: New York (Plenum), 605-625.

Heirtzler, J. R., Veevers, J. J., et al., 1974. Site 263. In Heirtzler, J. R., Veevers, J. J., et al., Init. Repts. DSDP, 27: Washington (U.S. Govt. Printing Office), 279-335.

Howell, D. G., and von Huene, R., 1981. Tectonics and sediment, along active Basins. In Douglas, R. G., Colburn, I. P., and Gorsline, D. S. (Eds.), Depositional Systems of Active Continental Margin Basins: Short Course Notes. Soc. Econ. Paleontol. Mineral. Pacific Section, pp. 1-13.

Ibach, L. E. J., 1982. Relationship between sedimentation rate and total organic carbon content in ancient marine sediments. Bull. Am. Assoc. Petr. Geol., 66:170-188.

Ingle, J. C., Jr., 1980. Cenozoic paleobathymetry and depositional history of selected sequences within the Southern California Borderland. Memorial to Orville L. Bandy, Cushman Foundation Spec. Publ., 19:163-195.

Jenkyns, H. C., 1976. Sediments and sedimentary history of the Manihiki Plateau, South Pacific Ocean. In Schlanger, S. O., Jackson, E. P., et al., Init. Repts. DSDP, 33: Washington (U.S. Govt. Printing Office), 873-890.
1980. Cretaceous anoxic events: From continents to oceans. J. Geol. Soc. (London), 137:171-188.

Jousé, A. P., 1978. Diatom biostratigraphy on the generic level. Micropaleontology, 24:316-326.

Kendrick, J. W., 1979. Geochemical studies of black clays from Leg 43, Deep Sea Drilling Project. In Tucholke, B. E., Vogt, P. R., et al., Init. Repts. DSDP, 43: Washington (U.S. Govt. Printing Office), 633-642.

Kendrick, J. W., Hood, A., and Castaño, J. R., 1978. Petroleum-generating potential of sediments from Leg 41, Deep Sea Drilling Project. In Lancelot, Y., Seibold, E., et al., Init. Repts. DSDP, 41: Washington (U.S. Govt. Printing Office), 817-819.

Kennett, J. P., 1977. Cenozoic evolution of Antarctic glaciation, the circum-Antarctic Ocean, and their impact on global paleoceanography. J. Geophys. Res., 82:3843-3860.

King, J. E., and Hida, T. S., 1957. Zooplankton abundance in the central Pacific, Pt. II. Fish. Bull. 118, 57:365-395.

Lancelot, Y., and Larson, R. L., 1975. Sedimentary and tectonic evolution of the northwestern Pacific. In Larson, R. L., Moberly, R., et al., Init. Repts. DSDP, 32: Washington (U.S. Govt. Printing Office), 925-941.

Larson, R. L., Moberly, R., et al., 1975a. Site 305: Shatsky Rise. In Larson, R. L., Moberly, R., et al., Init. Repts. DSDP, 32: Washington (U.S. Govt. Printing Office), 75-158.

1975b. Site 306: Shatsky Rise. In Larson, R. L., Moberly, R., et al., Init. Repts. DSDP, 32: Washington (U.S. Govt. Printing Office), 159-191.

1975c. Site 310: Hess Rise. In Larson, R. L., Moberly, R., et al., Init. Repts. DSDP, 32: Washington (U.S. Govt. Printing Office), 233-293.

LePichon, X., Eittreim, S. L., and Ludwig, W. J., 1971. Sediment transport and distribution in the Argentine Basin, 1. Antarctic bottom current passage through the Falkland fracture zone. Physics and Chemistry of the Earth (Vol. 8): Oxford (Pergamon), pp. $1-28$.

LePichon, X., Ewing, M., and Truchan, M., 1971. Sediment transport and distribution in the Argentine Basin, 2. Antarctic bottom current passage into the Brazil basin. Physics and Chemistry of the Earth (Vol. 8): Oxford (Pergamon), pp. 29-48.

Leyden, R., Bryan, G., and Ewing, M. 1972. Geophysical reconnaissance on African shelf, 2. Margin sediments from Gulf of Guinea to Walvis Ridge. Bull. Am. Assoc. Petr. Geol., 56:682-693.

Lisitzin, A. P., 1971. Distribution of siliceous microfossils in suspension and in bottom sediments. In Funnell, B. M., and Riedel, W. R. (Eds.), The Micropaleontology of Oceans: Cambridge (Cambridge Univ. Press), 173-195.

McCave, I. N., 1979. Depositional features of organic-carbon-rich black and green mudstones at DSDP Sites 386 and 387, western North Atlantic. In Tucholke, B. E., Vogt, P. R., et al., Init. Repts. $D S D P, 43$ : Washington (U.S. Govt. Printing Office), 411-420.

Meyers, P. A., Brassell, S. C., and Hay, W. W., 1981. Cretaceous black shales in Angola Basin of South Atlantic Ocean. Bull. Am. Assoc. Petr. Geol., 65:958.

Montadert, L., Roberts, D. G., et al., 1979. Site 399, 400, and Hole 400A. In Montadert, L., Roberts, D. G., et al., Init. Repts. DSDP, 48: Washington (U.S. Govt. Printing Office), 35-71.

Müller, P. J., and Suess, E., 1979. Productivity, sedimentation rate, and sedimentary organic matter in the oceans -1 . Organic carbon preservation. Deep-Sea Res., 26A:1347-1362.

North, F. K., 1980. Episodes of source-sediment deposition. 2. The episodes in individual close-up. J. Petr. Geol., 2:323-338.

Pisciotto, K. A., and Garrison, R. E., 1981. Lithofacies and depositional environments of the Monterey Formation, California. In Garrison, R. E., and Douglas, R. G. (Eds.), The Monterey Formation and Related Siliceous Rocks of California. Soc. Econ. Paleontol. Mineral. Pacific Section, pp. 97-122.

Rhoads, D. C., and Morse, J. W., 1971. Evolutionary and ecologic significance of oxygen-deficient marine basins. Lethaia, 4:413-428.

Ryan, W. B. F., and Cita, M. B., 1977. Ignorance concerning episodes of ocean-wide stagnation. Mar. Geol., 23:197-215.

Schlanger, S. O., and Jenkyns, H. C., 1976. Cretaceous oceanic anoxic events: causes and consequences. Geol. en Mijnbouw, 55: 179-184.

Schnitker, D., 1980. Global paleoceanography and its deep water linkage to the Antarctic glaciation. Earth-Sci. Rev., 16:1-20. 
Sclater, J, G., Hellinger, S., and Tapscott, C., 1977. The paleobathymetry of the Atlantic Ocean from the Jurassic to the present. $J$. Geol., 85:504-552.

Shaw, A. B., 1964. Time in Stratigraphy: New York (McGraw-Hill).

Suess, E., 1981. Phosphate regeneration from sediments of the Peru continental margin by dissolution of fish debris. Geochim. Cosmochim. Acta, 45:577-588.

Summerhayes, C. P., 1981. Organic facies of Middle Cretaceous black shales in deep North Atlantic. Bull. Am. Assoc. Petr. Geol., 65: 2364-2380.

Thiede, J., and van Andel, T. H., 1977. The paleoenvironment of anaerobic sediments in the Late Mesozoic South Atlantic Ocean. Earth Planet. Sci. Lett., 33:301-309.

Thierstein, H. R., and Berger, W. H., 1978. Injection events in ocean history. Nature (London), 276:461-466.

Tissot, B., Deroo, G., and Herbin, J. P., 1979. Organic matter in Cretaceous sediments of the North Atlantic: Contribution to sedimentology and paleogeography. In Talwani, M., Hay, W., and Ryan, W. B. F. (Eds.), Deep Drilling Results in the Atlantic Ocean: Continental Margins and Paleoenvironment: Washington (American Geophysical Union), pp. 362-374.

Tucholke, B. E., and Vogt, P. R., 1979. Western North Atlantic: Sedimentary evolution and aspects of tectonic history. In Tucholke, B. E., Vogt. P. R., et al., Init. Repts. DSDP, 43: Washington (U.S. Govt. Printing Office), 791-825.

Tucholke, B. E., Vogt, P. R., et al., 1979. Site 387: Cretaceous to Recent sedimentary evolution of the western Bermuda Rise. In Tucholke, B. E., Vogt. P. R., et al., Init. Repts. DSDP, 43: Washington (U.S. Govt. Printing Office), 323-391.

Vail, P. R., Mitchum, R. M., Jr., and Thompson, S., 1977. Seismic stratigraphy and global changes of sea level, Part 3: relative changes of sea level from coastal onlap. Am. Assoc. Petr. Geol. Memoir, 26:63-98.

Veeh, H. H., Calvert, S. E., and Price, N. B., 1974. Accumulation of uranium in sediments and phosphorites on the South West African shelf. Mar. Chem., 2:189-202.

Waples, D. W., 1982. Phosphate-rich sedimentary rocks: Significance for organic facies and petroleum exploration. J. Geochem. Explor., $16: 135-160$.

Weissert, H., McKenzie, J., and Hochuli, P., 1979. Cyclic anoxic events in the Early Cretaceous Tethys Ocean. Geology, 7:147-151.

Wyrtki, K., 1962. The oxygen minimum in relation to ocean circulation. Deep-Sea Res., 9:11-23.

Date of Initial Receipt: June 22, 1983

Date of Acceptance: August 12, 1983

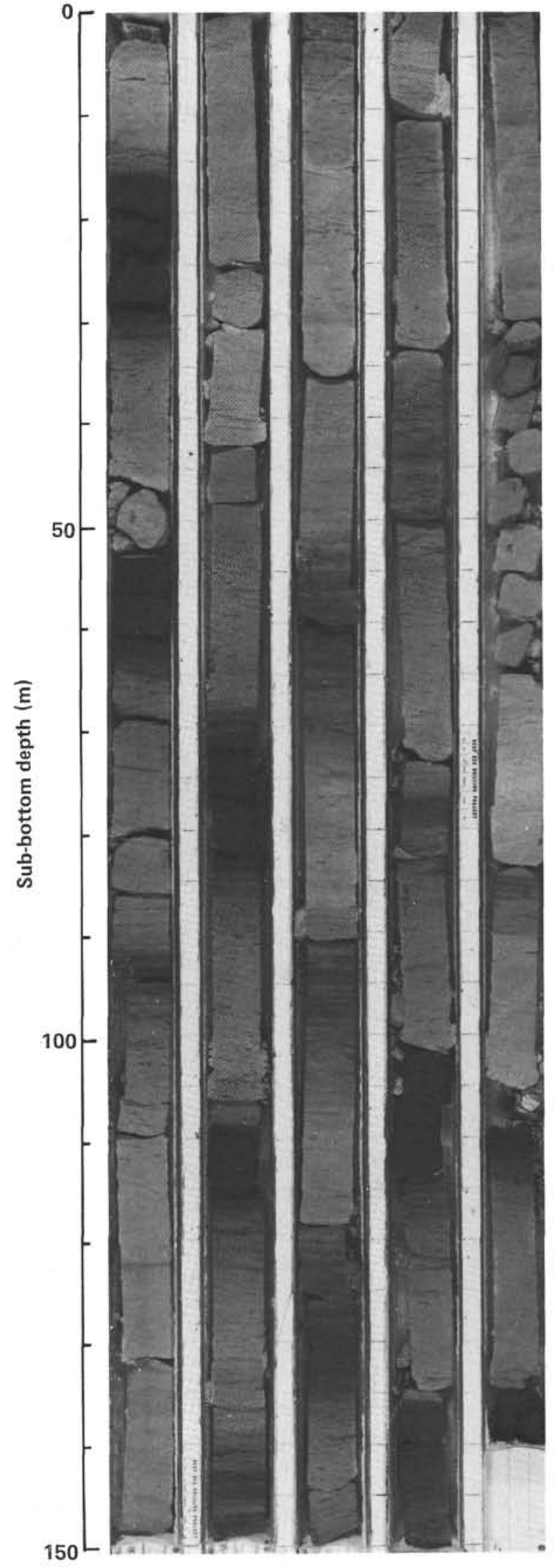

Figure 9. Alternating anoxic and oxic sediments in Core 17, Site 550 (middle Cenomanian). 
A Total
carbonate in water

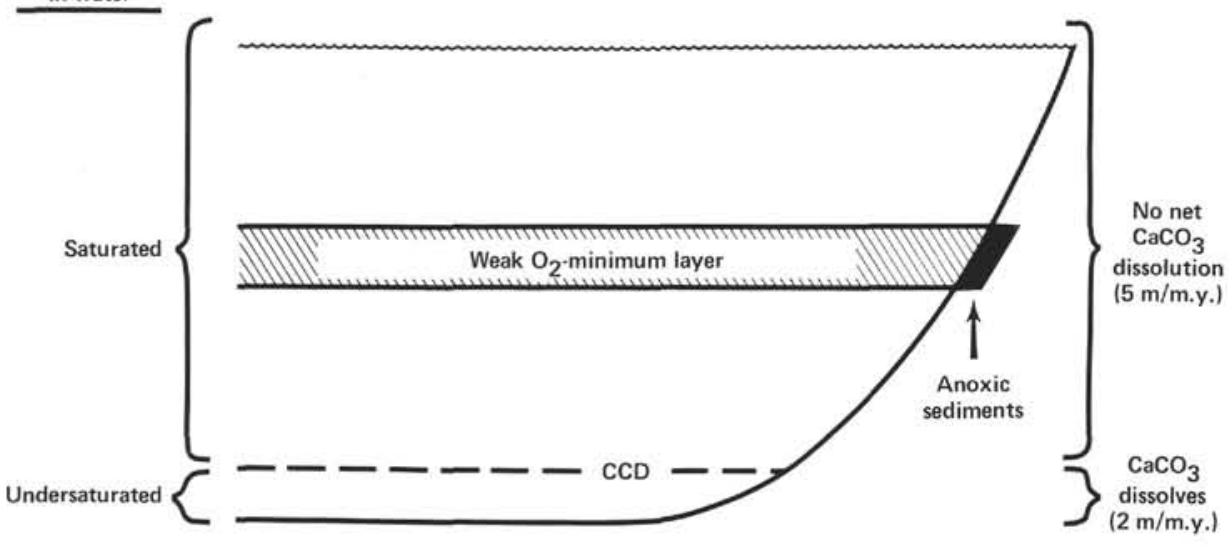

B Total carbonate Expanded $\mathrm{O}_{2}$-minimum layer in water (due to higher productivity

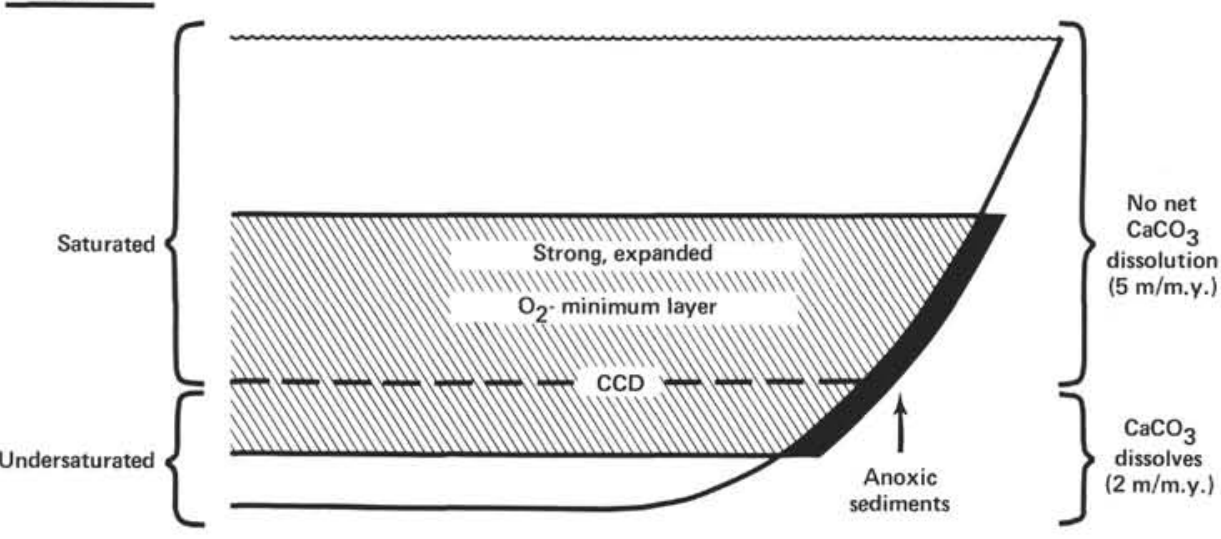

C

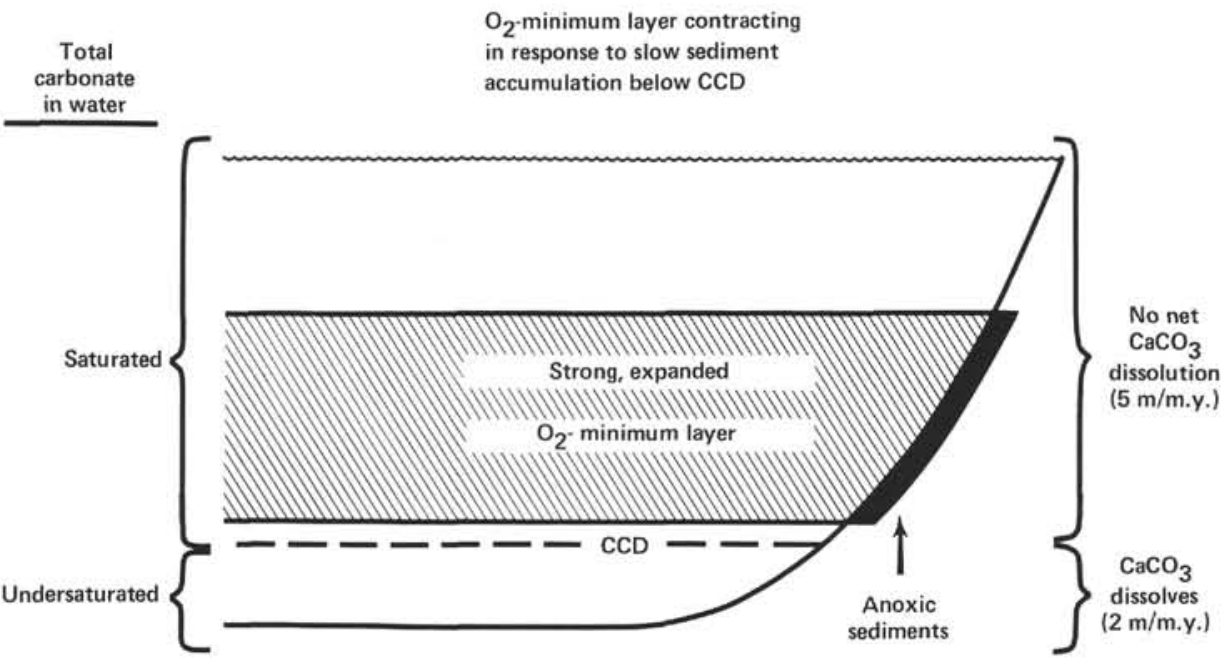

Figure 10. Model for interaction between CCD and oxygen-minimum layer. A. Weakly developed oxygen-minimum layer far above a deep CCD, representing a region of good circulation and modest productivity. B. Expanded, strongly developed oxygen-minimum layer. Increased preservation of organic matter in deepwater sediments has caused the CCD to rise. C. Lowered sediment-accumulation rate in sediments below $\mathrm{CCD}$ allows more oxidation or organic matter, causing oxygen-minimum layer to contract. Eventually the CCD may reach an equilibrium with the effective bottom of the oxygen-minimum layer. 